This is the version of the article accepted for publication in International Journal of Hindu Studies, 17 (3). pp. 401-444, published by Springer

https://doi.org/10.1007/s11407-014-9146-x

Accepted version downloaded from SOAS Research Online: http://eprints.soas.ac.uk/35262

Re-use is subject to the publisher's terms and conditions

\title{
Rājayoga: The Reincarnations of the King of All Yogas
}

\section{Jason Birch}

In the late nineteenth and twentieth century, prominent Indian religious leaders such as Svāmī Vivekānanda and Svāmī Śivānanda developed systems of Yoga based on Patañjali's Aștāngayoga and called them Rājayoga. They have promoted the Yogasūtra as the most authoritative source on Rājayoga. In contrast to this, there are modern Indian systems of Rājayoga which have very little to do with Pātañjalayoga, such as the one taught globally by the Brahma Kumaris. It is generally accepted that Rajjayoga refers to types of Yoga which are based more on meditation than physical techniques such as postures (äsana), yet very little research has been done to explain why there are variations between modern systems of Rājayoga. Also, the term "rājayoga" (literally, "king-yoga") implies superiority, usually, over Hathayoga, but this raises the question of whether there was ever a justifiable basis for this claim of superiority, which I address here through examining the history of Rājayoga.

The history of the term "rājayoga" reveals that it did not derive from Pātañjalayoga. Indeed, it was not until the sixteenth century that this term was used in a commentary on the Yogasütra. The earliest definition of Rājayoga is found in the twelfth century, Saiva Yoga text called the Amanaska, which proclaimed Rājayoga to be superior to all other Yogas and soteriologies prevalent in India at that time. From the twelfth to the fifteenth centuries, Rājayoga was mainly used as a synonym for samādhi, yet after the sixteenth century, the textual evidence reveals many attempts to reinterpret the name and connect it with different systems of Yoga. 
This calls into question the presumption that a Yoga tradition's survival depends on its success at faithfully preserving ancient teachings. In fact, the prominence of Rājayoga and even the Yogasutra in the twentieth century is more a consequence of the role they have played in sanctioning innovation and in promoting the efficacy of meditation within the competitive environment of Hinduism's diverse soteriological practices. ${ }^{1}$

\section{Modern Interpretations of Rājayoga}

In examining Svāmī Vivekānanda's claim that the Yogasūtra was a textbook on Rājayoga, Elizabeth De Michelis (2004: 178) has observed that the identification of Pātañjalayoga with Rājayoga may first have been made by the Theosophists and popularized by Svāmī Vivekānanda's book, Raja Yoga. ${ }^{2}$ The pervasiveness of "Patañjali's Rājayoga" in both popular publications on Yoga and somewhat more scholarly ones ${ }^{3}$ reflects the influence of Theosophy and Svāmī Vivekānanda's books on modern

Yoga in India and outside it. ${ }^{4}$ Many of these authors were probably aware that the term "rājayoga" is absent in the Yogasūtra, the Yogabhāsya, Śankkara's Vivaraṇa, Vācaspatimiśra's Tattvavaiśāaradī, and Bhoja's Rājamārtanda. In fact, as far as I am aware, rājayoga does not appear in a Yoga text until after the eleventh century. However, it seems to have a longer history in Indian astrology, for it is found in at least two early genethlialogical works, in which context it denotes astrological signs that foreshadow the birth of kings (Pingree 1981: 82). ${ }^{5}$

Nearly all published books on Rājayoga acknowledge the Yogasūtra as the textual source for this Yoga, and the structure of their expositions is usually the eight auxiliaries (aștānga) of Pātañjalayoga. Often, their explanations of each auxiliary are a synthesis of various religious and philosophical ideas with meditation techniques, depending on the author's predilections. De Michelis (2004: 149-77) has shown how Svāmī Vivekānanda's Raja Yoga blends elements of Neo-Vedānta and Rāmakṛṣna's mysticism with concepts from Western science, philosophy, and occultism. His ideology was overlaid onto the basic framework of Aștāngayoga and the purusa-prakrti metaphysics. This process has also been described by Sarah Strauss (2005: 8-23), so there is no need for me to go into further detail here, though it is worth pointing out that a similar syncretic process is discernible in more recent works on Rājayoga, albeit with different 
philosophical and religious elements. For example, Svāmī Śivānanda (2010: 61-68) of Rishikesh wrote an entire chapter on the Yoga of devotion (bhaktiyoga) in his book on Rājayoga, whereas Svāmī Vivekānanda (2003: 73) hardly expatiated on devotion when discussing sūtras (that is, 2.1, 32 and 45) on "worshipping god" (î́svarapraṇidhāna). Also, Svāmī Vivekānanda (2003: 17) dismissed posture (āsana), claiming that Rājayoga has little to do with Hațhayoga, whereas Svāmī Rāma's book (1998: 22-55) on Rājayoga devotes thirty-three pages to posture, including detailed explanations of Hathayogic poses such as headstand, dhanurāsana, and mayūrāsana along with their therapeutic benefits. Therefore, it is clear that even these modern interpretations of Rājayoga, which are encased by the framework of Pātañjalayoga, differ from one another in their emphasis and on certain details of content.

\section{The Yogasūtra in Pre-Modern Syncretic Expositions of Yoga}

The use of the Yogasūtra as a framework for a new syncretic exposition of Yoga was not an innovation of Svāmī Vivekānanda. Indeed, he was following, perhaps unknowingly, in the footsteps of several medieval writers of Sanskrit Yoga compilations, in particular, Śivānandasarasvatī and Bhavadeva. ${ }^{6}$ The most prodigious work of these two is Sivānandasarasvatī's Yogacintāmani which was written in the late sixteenth or early seventeenth century ${ }^{7}$ and has been estimated to have 3423 verses. $^{8}$ The Yogacintāmani integrated newer and older Yoga traditions of that time with material from the Purānas, Dharmaśāstras and epics, within the framework of Aștāngayoga. Śivānandasarasvatī traces his lineage back to Śankkara, ${ }^{9}$ and Advaitavedānta viewpoints are indeed enmeshed in his commentary, which was written for the more learned Brahmin who appreciated not only the complexities of the Yogasūtra and its commentaries, but also the new discourse created by juxtaposing and blending together different systems of Yoga. Indeed, just as Svāmī Vivekānanda's Raja Yoga combines practical instruction on prānāyamma and meditation with a lofty discourse on Eastern and Western esoteric teachings, the Yogacintāmaṇi combined the practical instructions of earlier Hathayoga texts with the philosophy and metaphysics of Pātañjalayoga, Advaitavedānta, Tantric Śaivism, and so on. However, the difference in this regard is that the Yogacintāmaṇi embraced Hațhayoga, whereas Svāmī Vivekānanda (2003: 18) rejected it and preferred to invoke Śankarācārya as an authority on 
alternate nostril breathing. ${ }^{10}$

In the West, the term "yoga" tends to refer to postural practice and "meditation" to seated practice. ${ }^{11}$ A similar distinction is seen in the dichotomy of Hațhayoga and Rājayoga which is prevalent in India. Svāmī Vivekānanda (2003: 17) not only separated Rāja from Haṭhayoga, but also advocated the independence and superiority of the former over the latter. Indeed, in his view, Hathayoga was merely concerned with making the physical body strong, and he believed there were other, more effective ways to do that. ${ }^{12}$ Svāmī Śivānanda maintained the distinction of Rājayoga as mental practice and Hathayoga as physical, but he also integrated Hathayoga into Aștānngayoga by equating it as the auxiliaries of āsana and prānāyāma. His justification for this is worth quoting in full:

Hatha Yoga concerns with the physical body and control of breath. Raja Yoga deals with the mind. Raja Yoga and Hatha Yoga are interdependent. Raja Yoga and Hatha Yoga are the necessary counterparts of each other. No one can become a perfect Yogi without knowledge of the practice of both the Yogas. Raja Yoga begins where properly practised Hatha Yoga ends...(Svāmī Śivānanda 2010: 38).

As also noted above, Svāmī Rāma integrated Hathayoga into Aștāngayoga in the same way, and he too interpreted Rajjayoga as the meditative practice (that is, the internal auxiliaries) and Hathayoga as āsana and prānāyāma. ${ }^{13}$ As will be seen below, there are antecedents in medieval Yoga traditions for the opposing views of Svāmī Vivekānanda and Svāmī Sivānanda on the Rāja-Hatha dichotomy as well as for construing Haṭhayoga as an auxiliary of Pātañjalayoga.

\section{Modern Räjayogas Independent of the Yogasūtra}

It should be noted that not all modern interpretations of Rājayoga adopt the Aștānnga format of Pātañjalayoga. A good example is the Rājayoga of Ram Chandra who hailed from Shahjahanpur and founded the Shri Ram Chandra Mission in 1945. In his book entitled the Sahaj Marg Philosophy, he promoted his Rājayoga, which is also called the "Sahaj Marg," as a simple and easy way to realization (Chandra 2009: 331). ${ }^{14}$ His system begins with meditation (dhyāna) which he acknowledges to be the seventh 
step in Pātañjalayoga. Indeed, it is clear that he saw his own Rājayoga as a simplification of Pātañjalayoga: the last two auxiliaries of Aștāngayoga are retained as well as the practice of renunciation (vairāgya). ${ }^{15}$ Ram Chandra (2009: 169) referred to Svāmī Vivekānanda as an authority on spiritual matters, so his understanding of Pātañjalayoga as Rājayoga probably derives from Svāmī Vivekānanda's work. Nonetheless, there is very little of Pātañjalayoga's metaphysics, terminology, or structure in the Sahaj Marg's Rājayoga.

Seeing that the above Rājayogas have been uniquely shaped by the teachings of their founding gurus, it is likely that there are other modern systems of Rājayoga which are unknown outside of India. Though I suspect that most of these have been based, to some degree, on Pātañjalayoga since the time of Svāmī Vivekānanda, there is at least one Rājayoga whose name and content is entirely independent of Pātañjalayoga. It is taught by the Brahma Kumaris, a global organization founded by Prajapita Brahma (aka Dada Lekhraj) in the late 1930s. The Brahma Kumaris teach a system of Rājayoga without reference to or any discernible influence from Svāmī Vivekānanda's Rājayoga or Pātañjalayoga, because they believe that their teachings emanate directly from Siva and that they represent the pure tradition from which "Hinduism" has become the corrupted version. ${ }^{16}$

One publication of the Brahma Kumaris defines their Rajjayoga as follows:

Raja Yoga means the intellectual and loveful communion of the soul with the Supreme Soul....Initiation, Meditation, Concentration and Realization are the four steps of Raja Yoga. Raja Yoga subsumes within itself the fundamentals of all methods of Yoga and confers the achievements of all of them naturally and easily, using one very simple method which anyone can learn (1986: 60). ${ }^{17}$

This definition appears to have been inspired by the meaning of Yoga as "union," which is salient in Śaiva Tantras (see Vasudeva 2004: 235-46) as well as the medieval Yoga traditions that followed them. The term "rāja," which literally means "king," is being understood metaphorically as the supreme soul; Rājayoga is thus the union of the individual soul with the supreme one. A later publication acknowledges Pātañjalayoga to be the "Raja Yoga...commonly known throughout the world" (Brahma Kumaris 1996: 129), yet it rejects Pātañjalayoga's authority on the grounds 
that the meaning of Yoga as "union" is not evident in the Yogasūtra. ${ }^{18}$ The preface of the same publication also defines Rajjayoga as "the King of Yogas or the Royal Yoga" (Brahma Kumaris 1996: 4), ${ }^{19}$ which is affirmed by their official website. ${ }^{20}$ This definition of Rājayoga is well attested in earlier Śaiva Yoga traditions.

\section{The History of Rājayoga}

\section{The Rājayoga of the Amanaska and the Aparokșānubhūti}

The earliest extant definition of Rajjayoga occurs in the second chapter of a Śaiva Yoga text called the Amanaska, which was written before the twelfth century. ${ }^{21}$ In answering Vāmadeva's opening question, Siva states that there is an internal Yoga (antaryoga) called Rājayoga, and he defines it in two ways. It is called Rajjayoga, first, because it is the king of all Yogas and, second, because it enables the yogin to reach the illustrious king, the supreme Self. ${ }^{22}$ The first definition is a broad declaration of Rājayoga's superiority over all Yoga systems known at that time. Though these other Yogas are not named, it is likely that the author had in mind Mantrayoga, Layayoga, and Hathayoga because other verses in the Amanaska explicitly reject mantras (for example, 2.7) and Hathayogic practices such as āsanas, prānāyāma, mudrās and bandhas (2.7, 2.31, $2.42)$ as well as meditation techniques (dhyāna) $\left(2.33,2.37\right.$, and 2.39). ${ }^{23}$ The superiority of Rājayoga over these three other Yogas is affirmed by most medieval Yoga texts which teach the tetrad of Mantrayoga, Layayoga, Hathayoga, and Rājayoga. However, unlike the Amanaska, they promote the first three Yogas as acceptable methods for attaining Rajjayoga. The Amanaska dismisses the other Yogas, in much the same way as Svāmī Vivekānanda dismissed Hathayoga, and both base their dismissal on the critique that Hathayoga's techniques are difficult to perform and its purpose questionable. The Amanaska (2.42ab) states:

abhyastaih kim u dīrghakālam anilair vyādhipradair duṣkaraih prānāyāmaśatair anekakaraṇair duhkhātmakair durjayaiḥ I

What is to be gained by [manipulating] the vital winds, [even when] practiced for a long time? [What gained] by the hundreds of [ways] of holding the breath, which cause sickness and are arduous, and by the 
many $m u d r \bar{a},{ }^{24}$ which are painful by nature and difficult to master?

\section{Svāmī Vivekānanda's Raja Yoga states:}

We have nothing to do with [Hațhayoga] here, because its practices are very difficult, and cannot be learned in a day, and, after all, do not lead to any spiritual growth (2003: 17).

The Amanaska also rejects gradualist Yoga techniques for attaining samā$d h i$, which would include any system based on auxiliaries (that is, Șậngayoga, Aștāngayogoga, and so on). ${ }^{25}$ The Amanaska's Rājayoga is presented as an easy, direct, and simple way to $s a m \bar{a} d h i,{ }^{26}$ which is described as a natural state (sahajāvasthā). Such rhetoric appears to be a clear precedent to the Brahma Kumaris' definition cited above, as well as Ram Chandra's Rājayoga which dispensed with the first six auxiliaries of Aștāngayoga and was promoted by its founder as a direct and easy method and as the "king of yogas" (2009: 122). Indeed, the Amanaska's position is more extreme than Ram Chandra's, because it begins and ends with samādhi whereas Ram Chandra accepted the seventh auxiliary of Pātañjalayoga (that is, dhyāna) and taught meditation for the attainment of samādhi. On meditation and the natural state of samädhi, the Amanaska's position is made clear in verse $2.33 \mathrm{bd}$ :

\section{...dhyānādikarmākulāḥ I}

prāyah prāṇigaṇā vimūụhamanaso nānāvikārānvitā

dṛ́syante na hi nirvikārasahajānandaikabhājo bhuvi ॥

[...Some] are confounded by activities such as meditation. Generally speaking, [these] multitudes of people have deluded minds and various [mental] disturbances. For, those who experience nothing but the bliss of the undisturbed, natural state [of samādhi] are not seen in the world.

The Amanaska's second definition of Rājayoga is based on the metaphor that the supreme Self (paramātman) is a "king" (räjan). This metaphor is found in one of the oldest Upanișads, the Bṛhadāranyaka (2.5.15):

sa vā ayam ātmā sarveșām bhūtānām adhipatih sarveșām bhūtānām rājā I 
This very Self is also the ruler of all beings, [that is to say,] the king (rāja) of all beings.

This more esoteric meaning of Rājayoga reminds us of the Brahma Kumaris' definition of Rajayoga as "communion of the soul with the Supreme Soul." However, in the Amanaska the word "yoga" is better understood as "method" (that is, the method for [attaining] the Self) because its second definition indicates that Rajjayoga is the means by which the yogin attains the Self. ${ }^{27}$ Therefore, in the context of the Amanaska, Rājayoga is the no-mind state (amanaska) and both terms (that is, rājayoga and amanaska) are synonyms in the Amanaska and later Yoga texts. ${ }^{28}$

Apart from the metaphor of the supreme Self as king in the Amanaska's second definition of Rājayoga, it also plays on the root meaning of $r \bar{a} j$ as "to shine," ${ }^{, 2}$ in order to affirm Rajjayoga as the method for realizing the "shining" (dīpyamāna) Self.

In light of the modern association of Rājayoga with the Yogasūtra, it should be noted that the Amanaska was not influenced directly by Pātañjalayoga. Key elements of the latter such as the purusa-prakrti metaphysics and the levels of samādhi, Kriyāyoga, and Aștāngayoga are absent in the Amanaska. The teachings of the Amanaska, which are spoken by Siva, undoubtedly derive from earlier Śaiva traditions; for example, its central technique called Śāmbhavī Mudrā was known to the Kashmirian Śaiva exegetes, Abhinavagupta and Kṣemarāja, as Bhairava Mudrā. ${ }^{30}$ Its rejection of gradualist approaches to liberation and its dislike of austerities (tapas) point to the influence of later Kaula schools whose texts also include terms such as amanaska and unmani as synonyms for samādhi. ${ }^{31}$ Nonetheless, the Amanaska rejected Tantric sectarian affiliation, mantras, and ritual which suggests that it was conceived as a reformation of earlier Śaiva traditions. By emphasizing samādhi as well as practice (abhyāsa), detachment (audāsinya), and the guru's favor (guruprasāda) as the essential means to liberation, the Amanaska placed itself firmly among the Yoga traditions which became prominent from the twelfth century onwards.

Although the Amanaska provides the earliest extant definitions (nirvacana) of Rājayoga, it may not be the earliest Yoga text in which the term occurs, because the Aparokșānubhūti has preserved a Vedāntic system of Yoga with fifteen auxiliaries ( $a \dot{n} g a$ ) called Rājayoga. This text has been attributed to Âdiśankkara, however it was probably written only 
a century or two before its terminus ad quem of the fourteenth century. ${ }^{32}$ The Aparokșānubhūti's teachings on Yoga stand at a distance from the Amanaska because its Rājayoga is more of an attempt to homologize the auxiliaries of Yoga with Vedāntic doctrine and it appears to have had little influence on later Yoga traditions until the South Indian recension of the Yoga Upanișads. ${ }^{33}$ Also, the Aparokșānubhūti is unique in using the term "räjayoga" to denote a system of Yoga without the connotation of samādhi. In other medieval Yoga texts, Rājayoga is both a name for a type of Yoga based primarily on the practice of samädhi as well as a synonym for the state of samādhi itself (see Birch 2011: 542-43). Nonetheless, the Aparokșānubhūti has led to the association of Śankarācārya and Vedāntic teachings with Rājayoga as seen in the title of Manilal Nabhubhai Dvivedi's work, Rája Yoga, or The Practical Metaphysics of the Vedanta: Being a Translation of the Vákyasudhá or Drigdrishyaviveka of Bháratitirtha, and the Aparokshánubhuti of Shri Shankaráchárya, which was published in 1885 .

\section{Early Räjayoga and Hațayoga}

From the Amanaska until the fifteenth-century Hathapradipika, the meaning of Rājayoga as the practice of samādhi was ubiquitous among Yoga texts. However, unlike Mantrayoga and Hațhayoga which were largely characterized by specific techniques, Rājayoga was associated with a diverse range of techniques, and for this reason, no typology of a system of Rājayoga is apparent. For example, in the Amanaska, Sāmbhavī Mudrā was the main technique for achieving Rājayoga (that is, samādhi), but in the Dattâtreyayogaśāstra and the Yogabija, Mantrayoga, Layayoga and Hathayoga were the means to Rājayoga. ${ }^{34}$ In contrast to this, the Amaraughaprabodha states that Rajjayoga is achieved by fusing the mind with an internal sound.$^{35}$ It also teaches the same tetrad of Yogas in the Dattātreyayogaśāstra and the Yogabija and similarly affirms that the first three are for the attainment of Rajayoga, ${ }^{36}$ so one could infer that the first three Yogas cause the internal sound and the mind's fusion with it. Yet, one might also infer that any technique which brings about the internal sound and the mind's fusion with it would be equally valid. The Śärngadharapaddhati ${ }^{37}$ and the Sivasamhitā teach the same tetrad of Yogas, but their explanations of Rājayoga are even more disassociated from the other three Yogas than is the case in the Amaraughaprabodha. 
In both texts, Rājayoga is brought about by visualization and meditation practices involving Cakras and Kuṇualinī. ${ }^{38}$

The attainment of Rājayoga by Hațhayoga is the central theme of the

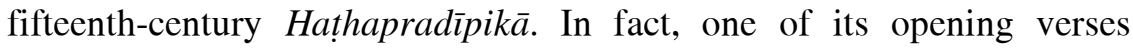
confirms that there were numerous conflicting views on how to achieve Rājayoga at the time it was written:

\section{bhrāntyā bahumatadhvānte rājayogam ajānatām I \\ hațhapradīpikām dhatte svātmārāmah krpākaraḥ ॥}

The compassionate Svātmārāma has composed [this work called] the "Light on Hațhayoga" for people ignorant of Rājayoga because they are lost in the darkness of many [different] opinions [on it] (Hathapradīpikā 1.3).

Svātmārāma solved the problem of conflicting views by amalgamating many different Yoga systems into one method which he called Hathayoga. He then promoted Hathayoga as indispensable for Rājayoga in terms almost identical to those of Svāmī Śivānanda cited above:

hațam vinā rājayogo rājayogạ̣ vina hațhạ I

na sidhyati tato yugmam a nispatteh samabhyaset ॥

Without Hațha, Rājayoga does not succeed, and without Rāja, nor does Hathayoga. Therefore, the [yogin] should practice both until the [fourth and final stage of Yoga called] Niṣpatti [is attained] (Hațapradīpika $2.76=$ Śivasaṃhitā 5.222).

Svātmārāma used the assortment of various meditation techniques associated with Rājayoga in earlier Yoga texts to compile the Hathapradīpikā's fourth chapter on samāahi. ${ }^{39}$ This chapter is perhaps the most concise and complete digest on Rājayoga in a medieval Yoga text. It focuses on Śāmbhavī and Khecarī mudrās and Nādānusandhāna (that is, fusion of the mind with the internal sound) for the attainment of Rajjayoga. The Hathapradīpika and its source texts confirm a consensus on the meaning of Rājayoga as samādhi, but there is no such consensus on the means for achieving it, nor the mechanisms (that is, piercing of Cakras or knots, 
and so on) by which it is achieved.

\section{Influence of the Pātañjalayogaśāstra and the Bhagavadgîtā on Early Hațayoga and Rājayoga}

One might wonder whether Pātañjalayoga influenced the Hathapradīpika and those of its source texts which teach Rājayoga. In my opinion, Patañjali's influence was marginal at most, for none of these texts incorporate the purusa-prakrti metaphysics nor the various levels of samädhi seen in his Yogaśāstra. Furthermore, Aștānngayoga is rare in these texts, and in the one case where it was incorporated (that is, Dattātreyayogaśāstra 27130), the auxiliaries are described in terms different to those of Pātañjalayoga. ${ }^{40}$ Indeed, the Rajjayoga of medieval texts is the stone-like samādhi of ascetic traditions which predate the Yogaśāstra (see Bronkhorst 1993: 20-28). The definition of Yoga in Yogasūtra 1.2 (yogaś cittavrttinirodhah) encapsulates the simplicity of this ascetic practice which is obscured by the complexities of other sütras. A similar definition of Rājayoga is found in Amaraughaprabodha 4d (yaś cittavrttirahitah sa tu räjayogah) which might be seen as a rare salute to the Yogaśāstra, yet the absence of any further terminology, theory, or practice of Pātañjalayoga in the Amaraughaprabodha merely accentuates the remoteness of the Yogaśāstra from this Rajjayoga. The compound cittavrttinirodha also occurs in the Amanaska (1.53) in a description of the supernatural power (siddhi) of knowing smells from afar. Such occurrences of cittavrttinirodha confirm that it had become somewhat of a cliché by the fifteenth century ${ }^{41}$ and it is likely that it was used simply as another expression for samādhi in texts such as the Amaraughaprabodha and the Amanaska.

As in the case of the Yogasūtra, it appears that the Bhagavadgīta had little influence on the Hathapradipika and its sources. Though the Hathapradīpika contains verses which can be traced back to various texts such as the Moksopāya and Kaulajñannanirnaya, there is not one from the Bhagavadgit $\bar{a} .{ }^{42}$ The same is true for the Amanaska, so it is unlikely that its adaptation of the term "rājayoga" was inspired by rājavidyā (that is, "the king's knowledge") which is mentioned in Bhagavadgitta 9.2.

\section{Räjayoga After the Fifteenth Century}

After the time of the Hațapradīpikā, further variations on Rājayoga emerged in Hathayoga texts such as the seventeenth-century Hatha- 
ratnāvalī which defined a rājayogin as one who could retain his semen. ${ }^{43}$ Also, the long recension of the Yogaśikhopanișat incorporated much of the Yogabija and added several verses to the latter's brief explanation of Rājayoga. ${ }^{44}$ Thus, in the Yogaśikhopanișat, Rājayoga is defined as the union of menstrual blood (rajas) and semen (retas). ${ }^{45}$ Christian Bouy (1994: 106) estimated that this Upanișad was redacted in the first half of the eighteenth century, but in a table of parallel verses between the Yogasikhopanisat and the Yogabija, he (104) reports that this verse is in the Yogasiddhämrta, which appears to be a South Indian transmission of the Yogabija. ${ }^{46}$ I have yet to find a quotation attributed to a Yogasiddhämrta in any medieval text, and it is conspicuously absent from Yoga compendiums such as Śivānandasarasvatī's Yogacintāmaṇi, the Upāsanāsārasangraha and the Yogasārasangraha, the first two of which quote the Yogabija. Therefore, the Yogasiddhāmrta may well be a late South Indian redaction of the Yogabija, and since the Yogaśikhopanișat is also a late work, it is probable that the definition of Rajjayoga as the union of sexual fluids arose after the time of the Hathapradipika ${ }^{47}$ This is further confirmed by two eighteenth-century works, Jayatarāma's Jogapradīpyaka and Sundardās' Sarvāingayogapradīpikā, which state that Rājayoga arises from the practice of Vajrolī Mudrā. ${ }^{48}$

By the eighteenth century many diverse practices were associated with Rājayoga by writers of various traditions. For example, Rājayoga is the sensual rapture (rāsalī $\bar{a})$ of the cult of the Goddess Tripurasundari (Śrīvidyā) in Mițthuśukla's Hamsavilāsa (Vasudeva 2012: 242-43), and in Narahari's Vedāntic compendium called the Bodhasāra, it is the fourteen stages of Yoga (yogabhümikā) taught in the Yogavāsistha (Cover 2012: 1-2). ${ }^{49}$ Seeing that the Yogavassistha, which is a rewriting of the earlier Moksopayya, provides a doctrine of liberation for kings (Hanneder 2009: 65), it is surprising that the term "räjayoga" did not appear in this text. In fact, my research has revealed only two texts which contain the gloss of Rājayoga as "the Yoga fit for kings." Both are eighteenth-century Vedāntic works, namely, the Rājayogabhāṣya ${ }^{50}$ and Divākara's commentary to the Bodhasāra. $^{51}$

The association of Rājayoga with the Yogavāsiștha was made by the sixteenth-century Vijñānabhikṣu, who, in his Sānkkhyasāra, overlaid Haṭhayoga and Rajjayoga onto a division between Yoga and gnosis in the Yogavāsiștha. ${ }^{52}$ In a sense, Vijñānabhikṣu was following the preference of 
earlier Advaitavedāntins for citing the Yogavassisțha in contexts of Yoga, the most conspicuous example being the fourteenth-century Vidyāranya in his Jivvanmuktiviveka. Like Vijñānabhikṣu, the eighteenth-century Ānandabodhendrasarasvatī also distinguished between Rājayoga and Hathayoga in his commentary on the Yogavāsiștha, but his distinction was not based exclusively on Yoga and gnosis, but on those Yoga techniques which are taught in the Yogavāsiștha (designated as Rājayoga) as opposed to those which are forceful and are not taught in scripture (Hathayoga). ${ }^{53}$

However, Rājayoga's association with the Yogavāsiștha was not the predominant one of the eighteenth century, because at that time, there were further formulations of a three-fold ${ }^{54}$ and six-fold Rājayoga, the latter of which attempted to bring together Sāmbhavī, Bhrāmarī, Khecarī, and Yoni $m u d r \bar{a}$ s as well as devotion (bhaktiyoga) and trance. ${ }^{55}$ Furthermore, unpublished manuscripts of Rājayoga texts in several libraries of Tamilnadu indicate a revival of Rajjayoga in South India in perhaps the eighteenth century or later. These include the Rajayogasiddhāntarahasya ${ }^{56}$ the Rājayogāmrta, ${ }^{57}$ the Rājayogasāra, ${ }^{58}$ and Agastya's Rājayoga ${ }^{59}$ The Rājayogāmrta is almost identical to the Rājayogasiddhāntarahasya, and the colophons of the former confirm its connection to the latter. ${ }^{60}$ The Rājayogasāra has verses in common with the Räjayogasiddhāntarahasya and Räjayogamrta, ${ }^{61}$ and these three texts are couched in the terminology and style of the Śaivāgamas. They take the form of a dialogue between Siva and the goddess and teach a series of visualization practices involving piercing the knots (granthi), seeing an internal light (jyotis), hearing an internal sound ( $n \bar{a} d a)$ and fusing the mind with it, and raising Kunḍalinī. Unlike the Amanaska, these texts are not polemical, but integrate other Yogas such as Haṭha, Sānkhya, and Laya. ${ }^{62}$ Indeed, the Rājayogasiddhāntarahasya (ms. R635, pages 5-6) gives an extensive description of Layayoga as the process of fusing the mind in ten sounds. Spontaneous retention (kevalakumbhaka) is mentioned in several passages on Rājayoga, but the practice of prānāyāma is omitted. Rājayoga is defined variously, including the visualization of that which is endowed with $n \bar{a} d a$, bindu, and kala within one's own internal light; ${ }^{63}$ the fusion of the mind in an internal sound ${ }^{64}$ and seeing a light in the internal sound. ${ }^{65}$

Agastya's Rājayoga differs from the above three in its content, terminology, and religious orientation which is Vaiṣnavism. It could well be 
part of a larger work because it begins with: "Now, the chapter on Yoga" (atha yogādhyāyah; ms. 4374, folio 1r). It consists of six sections (upadeśa) in which a series of visualization practices are taught involving meditation on the five gross elements (tattva), the manipulation of the breath, the repetition of om (pranava), visualizing Viṣnu, Kṛ̣na, Gañgā, Yamunā and Sarasvatī, and fixing (nyāsa) mantras in the body. There is very little mention of samadhi, yet the text begins with the lord's declaration: "I shall speak about Rājayoga...." ${ }^{\circ 6}$ All four of these South Indian texts on Rājayoga appear to be late works, because, as far as I am aware, they have not been cited in other texts and are conspicuously absent in compendiums such as the Yogacintāmani, Yogasārasañgraha, and Sundardeva's Hațatattvakaumudi $\bar{l}^{67}$ Unfortunately, none of the catalogs report a date of completion for any manuscript of these Rājayoga texts.

\section{Rājayoga and Haṭhayoga in Pātañjalayoga}

The earliest occurrence of the term "räjayoga" in a commentary on the Yogasūtra may be Vijñānabhikṣu's Yogasārasañgraha which is generally ascribed to the second half of the sixteenth century. It is reasonably clear that Vijñānabhikṣu understood Rājayoga as $s a m \bar{a} d h i$, which was its predominant meaning before the sixteenth century. He does mention Rājayoga in relation to Hathayoga, but only to direct the reader to Hațhayoga texts for instruction on āsana because his concern was with the topic of samāadhi. ${ }^{68}$ Had he understood Rājayoga to be Pātañjalayoga as a whole, one would expect to see the term "rājayoga" in a much more prominent place in his commentary. Nonetheless, his comment confirms that he preferred not to mix Pātañjala and Hațhayoga, though he saw the opportunity to do so.

Such an opportunity was taken by the seventeenth-century Nārāyanạatïrtha. In his commentary on the Yogasūtra called the Yogasiddhāntacandrikā, he integrated various medieval Yoga systems into Aș̣āngayoga. As Ko Endo (1998: 34) has noted, Nārāyaṇatīrtha listed the following fifteen Yogas in his introduction to Yogasūtra 1.1: Kriyāyoga, Caryāyoga, Karmayoga, Hațhayoga, Mantrayoga, Jñānayoga, Advaitayoga, Lakṣyayoga, Brahmayoga, Śivayoga, Siddhiyoga, Vāsanāyoga, Layayoga, Dhyānayoga, and Premabhaktiyoga. In his commentary on Yogasūtra 1.34, he equates Hațhayoga with prānāyāma, ${ }^{69}$ and on Yogasūtra 1.20, Rājayoga with asamprajñātasamādhi. ${ }^{70}$ Since asamprajñātasamāadhi is 
the highest level of samādhi in Pātañjalayoga, it is clear that Nārāyaṇatirtha placed Rājayoga as the goal to be achieved by the other Yogas, as was the case in the standard medieval tetrad of Mantrayoga, Layayoga, Hathayoga, and Rājayoga. And he was certainly aware of the metaphor of the Self as the king:

tad uktam smrtau—samādhis tatra nirbījo rājayogah prakīrtitah I

dīpavad rājate yasmād ātmā saccinmayah prabhur iti I

It has been said in the tradition: "here, seedless samādhi is declared to be Rājayoga because the lord, the Self, which is identical with pure consciousness, shines like a lamp" (Yogasiddhāntacandrikā 1.20).

\section{Rājayoga Atop Fifteen Medieval Yogas}

Nārāyaṇatīrtha's Yogasiddhāntacandrikā may be the earliest work to overtly integrate Hathayoga into a commentary on the Yogasūtra. However, it was not the only one to form a hierarchy of fifteen medieval Yoga systems under Rājayoga. For, an almost identical list of Yogas is found in Rāmacandraparamahamsa's Tattvabinduyoga which was probably written in the seventeenth or early eighteenth century. ${ }^{71}$ This text also goes by the names of Tattvayogabindu, Yogabindu and Rajjayoga, ${ }^{72}$ and it shares significant parallel passages to a text called the Yogasvarodaya which is cited at length in the Prānatoṣin̄i of Rāmatoṣaṇa Vidyālaṃkāra who lived in Bengal in the early nineteenth century. ${ }^{73}$ In fact, the parallels between the Tattvabinduyoga and the Yogasvarodaya are so extensive that one of these texts must have been based on the other.

Rāmacandra's list of Yogas is identical to Nārāyanatīrtha's with the exception that the former omits the latter's Premabhaktiyoga. There appear to be no parallels between these two works other than the names of the various Yogas. This is largely because Nārāyaṇatīrtha's explanations are governed by the Yogasūtra on which he was commenting, whereas Rāmacandra's work is based on other Yoga traditions prevalent during his time. For example, as noted above, Nārāyaṇatīrtha equates Haṭhayoga with prānāyāma, but Rāmacandra describes two varieties of Hațhayoga which involve practices such as the satkarma (that is, dhauti, nauli, and so on) and visualization techniques. ${ }^{74}$ Nārāyanatīrtha's definition of Kriyāyoga follows Yogasūtra 2.1 as ascetic observances, recitation of scripture, and 
contemplation of İśvara (tapaḥsvādhyāyeśvarapraṇidhānāni kriyāyogah), whereas Rāmacandra defines it as cultivating patience, discriminative judgment, detachment, peacefulness, and contentment. ${ }^{75}$ Moreover, in the Tattvayogabindu, Rājayoga is not defined by the Yogasūtra's terminology of asamprajñātasamādhi or nirbijasamādhi, but by the niṣkala terminology of earlier theistic traditions. ${ }^{76}$

Many of the above Yogas in the Yogasiddhāntacandrikā and Tattvabinduyoga are also found in the Sarvāingayogapradīpika ${ }^{77}$ a Braj-bhāsa $\bar{a}$ work written by Sundardās who lived in the seventeenth century and was associated with the Dādupanthīs in Ghātrāa (Thiel-Horstmann 1983: 13). The four chapters (upadeś) of this work teach three tetrads of Yogas: the first, Bhaktiyog, Mantrayog, Layayog, and Carcāyog; the second, Hathayog, Rājayog, Lakṣayog, and Aștangayog; and the third, Sānkhyayog, Jñānayog, Brahmayog, and Advaitayog. He, too, saw Rājayoga as the best Yoga of all these Yogas, and, playing on the root meaning of $r \bar{a} j{ }^{78}$ he wrote that one who practices it, "shines" for a long time. ${ }^{79}$ Sundardās' description of the rājayogin is quite typical of that of a yogin in samādhi. ${ }^{80}$

\section{Concluding Observations on the History of Räjayoga}

The following conclusions can be made about Rājayoga from the Sanskrit sources mentioned above. First, the second chapter of the Amanaska is the earliest extant evidence for the definition of the term "rājayoga" in a Yoga text. Second, the absence of rājayoga in earlier Tantras, and particularly in the Mokssopāya, in which one would expect to find it, suggests that the term was not used in connection with Yoga before the tenth century. And finally, it is clear that with the exception of the Aparoksānnubhüti, the chief denotative meaning of Rājayoga in Yoga texts written before the fifteenth century was samädhi and its use in relation to sexual fluids, sexual practices such as Vajroli Mudrā, the Yoga of the Yogavāsiștha and Pătañjalayoga occur after this time. However, the connotative meaning of Rājayoga as the "best Yoga" is always implied when the term is used in medieval and modern texts. In the early Hathayoga and Rājayoga traditions, Rājayoga's superiority was implicit in the necessity of samädhi for attaining liberation while alive (jīvanmukti). After the fifteenth-century Hathapradīpika, various other traditions including modern writers such as Svāmī Vivekānanda adopted the name as an emblematic term for the superiority of their innovative reinterpretations of Yoga. 


\section{Three Entwined Traditions}

In Svāmī Vivekānanda's Raja Yoga, three traditions which have a history of their own converge: Rājayoga, Aștānngayoga, and Pātañjalayoga. The last two are generally identified as one tradition, but Aștāngayoga has had a life of its own ${ }^{81}$ and was adopted and reinterpreted by various Śaiva and Vaiṣnava traditions as well as by the great Jain scholar, Hemacandra. ${ }^{82}$ Their interpretations are devoid of the metaphysics and terminology which characterize Pātañjalayoga. The tradition of Pātañjalayoga is a complex one from the time of its inception, owing to the close relation of the Yogaśastra to Sānkhya as well as the fact that its later commentators (for example, Vācaspatimiśra, Śañkara, Vijñānabhikṣu, and so on) have identified themselves with other traditions. As Gerard James Larson (2009: 487-88) has pointed out, the Pātañjalayogaśāstra resembles a "common tradition" (samānatantra) which has remained outside any sectarian affiliation even though Śaivas and Vaiṣnavas have consulted it. Also, the Yogabhāṣa appears to have been the preferred reference text on Yoga for the more scholarly commentator, and its influence on the early traditions of Hathayoga and Rājayoga was at most marginal, as evinced by their Sanskrit texts such as the Amanaska and the Hațapradīpikā.

The success of any Indian Yoga text depends on whether it adds something new to past teachings, while also maintaining the eternal guise of the tradition which, in the case of medieval Yoga, emanated from a divine and timeless source. By using the Yogasütra to sanction his eclectic views and innovations, Svāmī Vivekānanda would have satisfied his public's thirst, whether Theosophist or otherwise, for seemingly ancient teachings. The Yogasūtra's aphoristic style and common tradition must have made it an attractive authoritative source to Svāmī Vivekānanda. Yet, one might wonder whether he would have deferred to the Yogasütra had it not contained Aștângayoga, because he and other modern gurus have relied on Aṣtānngayoga to give their own views a comprehensive structure and vital pertinence to the most salient practices and theories of Yoga. This is also evident in earlier Sanskrit works. For example, in the Bhägavatapurāna (3.28), Aṣtānngayoga serves to introduce a long description of a visualization practice on Viṣnu, within the framework of other auxiliaries such as $\bar{a}$ sana for sitting upright and prānāyāma for purifying the mind, which would have satisfied and, perhaps, attracted Vaiṣnava devotees with an 
interest in Yoga. Moreover, by including Așțāngayoga, the Bhāgavata faith was distinguishing its Yoga from Śaivism's Șadangayoga while also ensuring that it covered the essential auxiliaries of Yoga. ${ }^{83}$

A Sanskrit work would only be preserved if it was of value to someone, because scribes required payment for copying it. The extra-textual context for the transmission of Yoga texts is often assumed to be a living tradition of a lineage of gurus who combine the texts with oral teachings. Medieval Yoga texts repeatedly state that a guru is indispensable for success in Yoga. The Yogasūtra may well be an exception here, for it has endured on a scholarly plane as evinced by the erudition of its later commentaries such as Vācaspatimiśra's Tattvavaiśāarad̄ and compilations such as Śivānandasarasvatî’s Yogacintāmani. Though the Yogasūtra may have inspired learned Yoga practitioners of past centuries, it has survived in literature without an apparent lineage of gurus. The text's value to panditas would have greatly contributed to the survival of its manuscript tradition, and more recently, Svāmī Vivekānanda's Raja Yoga ensured the survival and prominence of the Yogasūtra in the twentieth century. Though Svāmī Vivekānanda was intent on "transmitting" philosophical ideas which were not in Pātañjalayoga, later works on Rājayoga such as those by Svāmī Śivānanda and Svāmī Rāma have more closely followed the content of the Yogasūtra, and the subsequent interest in Pātañjalayoga, particularly outside India, has prompted practitioners and scholars to make historical and philological investigations into the textual tradition. The Hathayoga texts appear to have played the same role in the development of modern Yoga. Like Svāmī Vivekānanda's Raja Yoga, translations and commentaries of Hatha texts have been written by prominent Yoga gurus who used them to sanction their innovations as well as to provide the structure and terminology of physical practices. This is evinced by the inclusion of Hațhayoga's auxiliaries (that is, șațarma, prānāyyama, mudrā-bandha, and so on) in most systems of modern Yoga.

\section{Final Remarks}

The ever-present connotative meaning of Rājayoga as the superior Yoga has ensured its survival as a name for a type of Yoga. Apart from the examples cited in Sanskrit sources above, the scope for word play based on this compound is evident even in recent times, such as in the publica- 
tions of the Brahma Kumaris:

Raja Yoga implies that those practicing it behave in a royal manner.... They become "carefree kings" unaffected by the sharp contrasts of sorrow and joy, gain and loss, success and failure, praise and defamation. Their royalty and wisdom do not permit them to violate the laws of nature..." (1996: 128).

Ernest Wood surmised that, "The adjective rāja means 'kingly' because the man becomes king or master of his own faculties..." (1954: 9). And in trying to explain Rājayoga's association with Pātañjalayoga, Georg Feuerstein suggested that, "It could refer to the fact that Patanjali's Yoga was practiced by kings, notably the tenth-century King Bhoja..." (2001: 29).

The history of the term reveals that it outlived the traditions which carried it to prominence in earlier centuries. Its survival points to the continuing importance of samādhi in Indian Yoga traditions as well as the constant competition between these traditions which have vied with one another in claiming to teach the "best Yoga." As a foil for Hathayoga, it represents the mental, meditative, advanced, and purely soteriological Yoga techniques as opposed to the physical, preparatory, and Siddhi-orientated ones. The fault-line between Hathayoga and Rājayoga is an offshoot of the more ancient tension between ritual and gnosis in Indian religions. The efficacy and effortlessness of Rājayoga as opposed to the gradual progress and effort required for Hathayoga is still advocated today for the same reasons.

\section{Notes}

1. I wish to thank Jacqueline Hargreaves, Elizabeth De Michelis, James Mallinson, Gavin Flood, Jürgen Hanneder, Giles Hooper, Zoe Slatoff, Jennifer Cover, and David Gordon White for reading an early draft of this paper and for their many helpful comments; thanks are also due to Andrea Acri for his editing and Mark Singleton for providing me with a copy of manuscript PM1428 of the Rājayogasāra. All quotations and references to the Hathapradīpika in this paper are from the 1998 Kaivalyadhama edition unless otherwise stated. 
The following abbreviations are used: ms. is "manuscript," mss. "manuscripts," and ed. "edition." The notation for conjectures, emendations, or corrections to the cited Sanskrit is as follows: devadatta ] conjecture : devadattā ed. : devadattam ms. 123. This means that I have conjectured "devadatta," whereas the edition has the reading "devadatta," and the manuscript, numbered 123 , has "devadattam."

2. The source of the Theosophists' conflation of Rājayoga with Pātañjalayoga is not clear. There is a reference to Rajjayoga as consisting of "eight stages" in Paul's A Treatise on the Yoga Philosophy (1882: 28) which was first published in 1851. The eight stages are the auxiliaries of Aștāngayoga, though Paul does not mention Patañjali, Așțāngayoga, or the Yogasütra. He simply says: "Yoga is chiefly divided into Raja Yoga and Hatha Yoga" (28). Paul and his book were known to Helena Petrovna Blavatsky, one of the founders of the Theosophical Society, who in her memoirs mentioned Paul and his informant, Captain Seymour, a British officer who went "native" and became a yogin (Neff 2003: 94). Also, the Theosophical society published Paul's book in 1888 (Singleton 2010: 52), so it is clear that the Theosophists were influenced by it. There are earlier references to rājayogins by Westerners such as the French physician, François Bernier (1620-88), and the English missionary, William Ward (17691823) (for a discussion of their comments on Rājayoga, see Schreiner 2013: 764), but they do not associate rājayogins with Pātañjalayoga. Indeed, Ward (1818: 349) mentions that Rājayoga derived from the Yogavāsiștha. I wish to thank David Gordon White for the reference in Paul's book.

3. Only a few examples of popular publications on Yoga can be given here: Svāmī Akhilānanda, Hindu Psychology: Its Meaning for the West (1948); Wood, Great Systems of Yoga (1954); Svāmī Satyānanda Sarasvatī, Asana Pranayama Mudra Bandha (1969); Svāmī Rāma, The Royal Path: Practical Lessons on Yoga (1979); Iyengar, Light on Yoga (1979); and Svāmī Śivānanda, Raja Yoga (2010 [1937]). Examples of scholarly accounts are: Frauwallner 1973: 225; Daniélou 1991: 91; and Feuerstein 2001: 2829. Feuerstein posits that the association between Rājayoga and Pātañjalayoga predates the Theosophists and Svāmī Vivekānanda, and his sixteenthcentury estimate appears to coincide with the occurrence of the term "rājayoga" in Vijñānabhikșu's commentary on the Pātañjalayogaśāstra; "[Rājayoga is] a comparatively late coinage that came in vogue in the 
sixteenth century C.E. It refers specifically to the Yoga system of Patanjali... and is most commonly used to distinguish Patanjali's eightfold path of meditative introversion from Hatha-Yoga..." (2001: 28). The problem with this view is that the term "rājayoga" in late Pâtañjala commentaries such as Vijñānabhikṣu's Yogasārasañgraha means samādhi and not Pātañjalayoga per se. For further details, see Birch (2011: 543n119).

4. In this paper, the term "modern Yoga" does not refer to a typology of Yoga, but more generally to Yoga taught and practiced in the twentieth century.

5. The term "rājayoga" is found in the Yavanajātaka, which predates the seventh century (Mak 2013: 17-18), and in his Brhajjātaka, the sixthcentury Varāhamihira has forty-four Rājayogas in addition to Yavana's thirty-two. I wish to thank Christopher Minkowski for drawing my attention to these Sanskrit works.

6. Bhavadeva wrote the Yuktabhavadeva which has been dated to 1623 CE by M. L. Gharote (Gharote and Jha 2002: xvi) on the basis of a manuscript colophon.

7. Śivānandasarasvatî’'s guru was Rāmacandrasadānandasarasvatī. The Yogacintamani can be dated on the basis of two of its oldest manuscripts both completed in $1630 \mathrm{CE}$ (for the first, see Bouy 1994: 77n333, and the second, Kaivalyadhama 2005: 226-27) and the fact that it borrowed from an earlier work of the same name written by Godāvaramiśra, dated by Gode (1953: 475) to the time of the monarch of Gajapati, Pratāparudradeva, who ruled in Orissa between 1497 and 1539 CE.

8. Yogacintāmañi, ms. 9785 (based on R635), page 257, line 14 (ślokasankhya 3423). This is a scribal comment that follows the final colophon.

9. As it is apparent from the introductory eulogy found in the Yogacint $\bar{a}$ maṇi, page 2: śrīvyāsam yatiśankkarạ̣ bhavagurum śrīrāmacandrạ̣ gurum sāndrānandapadāmbujam ca sakalān natvā hi yogīśvarān | nānāgranthapayodhimadhyapatitam śrīyogacintāmanị niḥseșārthasamarthakam yatiśivānandah karoti sphuțam.

10. Svāmī Vivekānanda teaches none of the postures specific to Hathayoga, nor does he mention the bandhas or individual prāna āyämas such as Bhastrikā which are distinct to Haṭhayoga. Though Svāmī Vivekānanda

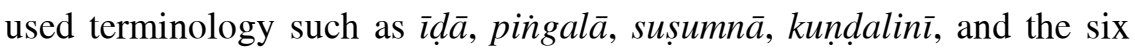
Cakra system which is redolent of earlier Hathayoga texts (for example, the Vivekamārtanda and the Sivasamhitāa), such terminology is also present 
in chapters on prānāyāma in late Tantric texts (for example, chapter 25 of the Rudrayāmalottaratantra), various Purānas (for example, the first part of the Bṛannāradīyapurāna, chapter 33), and alchemical/Āyurvedic texts (for example, the first part of the Ānandakanda, chapter 20). By the late nineteenth century these terms were probably widely known in India. They were certainly known to nineteenth-century Theosophists through the Yoga Upanișads. For example, the Yogacūdāmani, Dhyānabindu, and Garbhopanisat were translated by members of the Kumbakonam Theosophical Society and published in 1891 (see The Theosophist 12, 2 [May 1891 to September 1891]).

11. On the distinction between postural practice and meditation in modern Yoga, see De Michelis (2004: 8).

12. Svāmī Vivekānanda advocated that willpower alone was enough to keep the body strong: "There is not one muscle in the body over which a man cannot establish a perfect control; the heart can be made to stop or go on at his bidding, and, in the same way, each part of the organism can be made to work at his bidding" (2003: 17). For further citations on this, see De Michelis (2004: 160).

13. In a glossary, Svāmī Rāma defines Rājayoga as follows: "[It is the] 'Royal path.' Raja Yoga is the classical system of yoga philosophy and practice codified by the sage Patanjali in the Yoga Sutra. It is also known as the eight-limbed (ashtanga) yoga because it is divided into eight steps, some of which were elaborated into separate, specialized areas of discipline. Hatha yoga, for instance, is the science of psychophysical culture which developed out of the third limb, asana, or posture. Raja yoga is also used to signify the last four limbs taken together; pratyahara,...dharana,... dhyana,... and samadhi..." (1998: 131).

14. The introduction of Ram Chandra's Sahaj Marg Philosophy states: "[Ram Chandra] introduced an improved system of Raja Yoga which later came to be known as 'Sahaj Marg'" (2009: 292). It appears that the reason for the change of name was to avoid confusion between Patañjali's Rājayoga and Ram Chandra's Rājayoga. In his book called the Efficacy of Raja Yoga, Ram Chandra reveals the reason behind the simplicity of his Rājayoga: "The difficult methods, so far applied for attaining this simple thing [that is, the Sahaj Marg], have really made it complicated and intricate....Suppose a needle falls on the ground and you want to pick it up. It will be very easy to do so with the help of your fingers. If 
however a crane...or some other complicated machinery is used for picking up the needle, it will be difficult to do so, and it is quite possible you may fail in your attempt. Exactly the same thing happens when you think of difficult and complicated methods for attaining the Reality which is very simple" (2009: 169-70).

15. Ram Chandra states: "Under Sahaj Marg system of training we start from dhyan, the seventh step of Patanjali Yoga, fixing our mind on one point in order to practice meditation....The practice followed in our Mission is meditation on the heart. The same method has been recommended by Patanjali" (2009: 331). More recent writings of the Sahaj Marg movement state that the first six auxiliaries of Aștanngayoga have been omitted in order to suit the lifestyle of a modern householder. In an online document entitled the Basics of Sahaj Marg, Durai states: "Sahaj Marg is the ancient raja yoga modified and simplified to suit the lifestyles of modern human beings, particularly the grihastha (householder). Here an aspirant is inducted into meditation directly, bypassing the preliminary stages mentioned above." These preliminary stages are those of Aștāngayoga (that is, yama, niyama, āsana, and so on) which Durai had listed in a previous paragraph.

16. I wish to thank Suzanne Newcombe for pointing this out to me (personal communication, March 18, 2013).

17. This definition of Rājayoga is confirmed by their official website: "What is Raja Yoga? Raja (King)-Yoga (Communication). Raja Yoga is communication between the self and the Higher Being (God)." See: http://www.bkwsu.org/srilanka/us/massachusetts/typeb.2009-07-23.5593 975822/typec.2009-07-23.9585163482 (accessed December 10, 2013).

18. “...Patanjali nowhere states that the object of yoga is to forge a mental link with this Supreme soul. He merely uses yoga to concentrate and control the various modifications of the mind" (Brahma Kumaris 1996: 129).

19. Elsewhere in the text (Brahma Kumaris 1996: 21), Rājayoga is referred to as the "Highest Yoga," which appears to derive from the "King of Yogas" definition.

20. http://www.bkwsu.org/srilanka/us/massachusetts/typeb.2009-07-23.5 593975822/typec.2009-07-23.9585163482 (accessed December 10, 2013).

21. This date is established on the likelihood that Hemacandra, the great Śvetāmbara Jain scholar, based most of the twelfth chapter of his Yoga- 
śāstra on the second chapter of the Amanaska. The parallels have been identified by Muni Jambuvijaya in his edition of the Yogaśāstra.

22. See, respectively, Amanaska 2.3cd (rājatvāt yyogānām rājayoga iti smrtah) and 2.4 (rājānam dīpyamānam tạ̣ paramātmānam avyayam I dehinam prāpayed yas tu rājayogah sa ucyate).

23. I am inferring that Layayoga was rejected by the Amanaska because the latter rejects the raising of Kuṇạalinī (2.14), gazing points (drsții) (2.37), and meditation techniques in general (2.33; see below) as methods for inducing the no-mind state. There are many systems of Layayoga (socalled because they "dissolve the mind"), but most are based on either fusing the mind in an internal sound (nādānusandhāna), piercing Cakras with Kundalinī or the use of gazing points. The first is mentioned in the Śivasamhitā (5.44), described at length in the Hațapradīpika (4.654.103), and named Layayoga in other texts such as the Sivayogadīpik $\bar{a}$ (1.6) and the Hathatattvakaumudī (54.1); the second is in the Śarrigadharapaddhati (4350-4363); and third is prevalent among the simple, esoteric techniques (sanketa) of Layayoga described in the Dattātrayayogaśāstra (15-26).

24. The term "karana" in Amanaska $2.42 \mathrm{~b}$ probably refers to Hathayogic $m u d r a ̄ s ~ s u c h$ as Viparītakaraṇī.

25. Amanaska 2.53: "And [the yogin] who is made content by bliss, becomes devoted to constant practice. When the practice has become ever steady, there is no prescribed method and no step by step progress" (ānandena ca santuștaḥ sadābhyāsarato bhavet I sadābhyāse sthirībhüte na vidhir naiva ca kramah). Saḍangayoga is rejected in 2.29.

26. The Amanaska's preferred method is summarized by verse 2.26: "Always avoid the [Yoga] with components, mind, and effort. Always adopt the [Yoga] without components, mind, and effort" (sakalam samanaskạ̣ ca sāyāsam ca sadā tyaja I niṣkalam nirmanaskạ̣ ca nirāyāsam sadā bhaja).

27. Note that the causative verb (präpayet) is used in Amanaska 2.4 (cited in note 22 above).

28. For example, in Amanaska 2.32d, the term "rājayoga" could only mean the no-mind state in the following compound; "[the state of] Rājayoga in which the mind is absent" (vigatanijamanorājayoga). In later Yoga texts, see Hațapradīpikā 4.3-4 (rājayogah samādhiś ca...amanaskạ̣...cety ekavācakāh). 
29. Dhātupātha 822: "rāj, in [the meaning of] shining" (rājọ dīptau).

30. Compare Amanaska 2.10 (antarlakșyam bahir drșțir nimeșonmeșavarjitā | eșā hi śāmbhavi mudrā sarvatantreșu gopitā) with Abhinavagupta's Mālinīślokavārttika 2.77cd (parabhairavamudrām tām antarlakș[y]abahirdṛ́sam); Abhinavagupta's Tantrāloka 5.80 (asaṃkocavikāso 'pi tadābhāsanatas tathā I antarlakșyo bahirdrștịh paramam padam aśnute); and Kșemarāja's Svacchandoddyota on 2.89c (viśālākșam iti antarlakșyo bahirdrșțir nīmeșonmeșavarjītah ity āmnātaparabhairavasphārāvasthitam).

31. For example, Kaulajñānanirnaya 14.83bd: “...My dear, [the yogin] becomes [motionless] like a piece of wood [or] a clod of earth, when the state of no mind of mind arises, $\mathrm{O}$ beautiful one" (...kāșthaval loștavat priye | manasya unmanībhāvo yadā bhavati sundari || 83 || 83a ürdhvamadhyam ] ms. NAK 3-362: ūrddhamadhyam ed.); Ūrmikaulārnavatantra 3.72: "Both Rudra and Rudra's Śakti go to absorption in amanaska. Thus, this Kaula [knowledge] has not been taught in the innumerable Brāhmanical and Śaiva scriptures" (rudraś ca rudraśaktiś ca amanaske layam gatau I tat kaulikam idam proktam na śāstrāgamakoṭibhih ॥ 72b amanaske ] conjecture : amanasthe codex. Apart from the fact that amanasthe is odd Sanskrit, my conjecture, amanaske, is supported by the quotation of 3.72ab in Jayaratha's commentary on Tantrāloka 3.67). For more information on Kaulism and its subitist teachings, see Vasudeva (2004: 444-45). Such teachings are also seen in the Vijñannabhairavatantra, a scripture of the Trika (Sanderson 1990: 74-76).

32. Strictly speaking, the terminus a quo of the Aparokșannubhūti is Âdiśankara which means that there is a window of at least five centuries in which this text may have been composed. However, for reasons I have stated previously (Birch 2011: 540), it appears more likely that the Aparo$k s \underline{a} n u b h \bar{u} t i$ was composed closer to its terminus ad quem (that is, the fourteenth-century Vidyāranya's Dīpikā) than its terminus a quo.

33. See Bouy (1994: 112-13) for details on sections of the Aparokșānubhüti borrowed by several Yoga Upanișads.

34. Dattātreyayogaśāstra 159cd-160ab: "[The yogin] should practice [Yoga] by means of all these [techniques of Mantrayoga, Layayoga, and Hathayoga] which have been taught [in this text]. Because of them (tato), Rājayoga arises in due course of time and certainly not otherwise" (etaih sarvais tu kathitair abhyaset kālakālatah | tato bhaved rājayogo nāntarā 
bhavati dhruvam); and in the Yogabija (143cd) the hierarchy is made clear: "Mantra, Hatha, Layayoga are sequentially the stages in Rājayoga" (mantro hațho layo rājayoge 'ntar bhümikāh kramāt। 143d rājayoge 'ntar bhūmikāh kramāt ] ms. 8627 : rājayogāntarbhūmikāh kramāt ed.).

35. Amaraughaprabodha 52-53ab: “...Then, having pierced Rudra's knot, the breath goes to his throne [in the middle of the yogin's eyebrows]. In the [state of] Nișpatti, a flute-like sound whose tone [is like that] of a resonating lute arises. Then, the mind becomes fused [with that] which is called Rājayoga" (rudragranthim tato bhitvā śarvapīthagato 'nilaḥ | niṣpattau vainavah śabdah kvanadvinnākvaṇo bhavet I| 52 || ekībhūtam tadā cittam rājayogābhidhānakam | 52b śarvapịtha ] Hațapradīpikā 4.76 : satvapịtha ed.). According to Brahmānanda's gloss on śarvapītha, in his Jyotsna $\bar{a}$ (4.76), Rudra's throne is in the middle of the eyebrows (śarvasyeśvarasya pịtham sthānam bhrūmadhyam...).

36. Amaraughaprabodha 73cd: "Laya, Mantra, and Hatha have been taught solely for [the attainment] of Rājayoga" (layamantrahațāh proktāh rājayogāya kevalam).

37. Part of the section on Yoga in the Sárngadharapaddhati corresponds to an Upanișad called the Yogarājopanișat. This Upaniṣad consists of verses 4347-4363 of the Sārngadharapaddhati. That the Yogarājopanișat is a late duplication of part of the Śarngadharapaddhati's Yoga section (or perhaps an unknown source text of the Särngadharapaddhati) is evinced by its omission of the latter's section on Rājayoga, which makes it an incomplete account of the Mantrayoga, Layayoga, Hathayoga, and Rājayoga that it claims to teach in its first verse (Yogarājopanișat $1 \mathrm{~cd}=$ Śārngadharapaddhati 4347ab): yogarājam pravakṣyāmi yoginām yogasiddhaye I mantrayogo layaś caiva rājayogo hathas tathā. This flaw in the Upanișad as well as the absence of citations in late Sanskrit compilations on Yoga suggests that it was redacted recently. My comments are based on one manuscript of the Yogaräjopanișat (ms. 46-461 at the Bharat Itihas Samshodak Mandal, Pune; the final colophon reads: iti yogarājopanisat samāptah) which has the same number of verses as the printed version (manuscript not reported) in the Adyar Library's Unpublished Upanishads (1938: 1-3).

38. The Śārngadharapaddhati (verses 4364-4371) offers a concise description of a Rājayoga which was perfected by Dattātreya and based on two methods. The first is piercing the three knots (granthi) by the mind 
and breath which are raised up the central channel by contracting the pelvic floor (that is, mülabandha). The second is piercing the five Cakras with Kuṇualinī which is awakened by creating upward surges of vitality (udghäta; on the meaning of this term, see Vasudeva 2004: 405-9). Outside Yoga traditions, the view that Rājayoga was achieved through visualizing Kuṇ̣alinī is mentioned by the fifteenth-century Rāghabhața in his commentary on Śāradātilakatantra 25.64: ... ātmānubhavaikagamyakuṇdalinīcintanarūpam rājayogādiprakāram....The Śivasaṃitāa omits definitions of Mantrayoga, Layayoga, and Hathayoga and instead describes over a dozen visualization and meditation practices, ranging from gazing at one's shadow in the sun to visualizing Cakras and raising Kunḍalinī (see 5.20-5.207). Having identified these as the Rajjayoga hidden in all the Tantras, a description of a Rājādhirājayoga, "the Yoga of the supreme king of kings," follows (5.208). This is merely another meditation practice of making the mind supportless and free of thought, with a discussion on the gnosis that comes from it (5.209-5.221).

39. Verses from the second chapter of the Amanaska, the Dattātreyayogaśāstra, and the Amaraughaprabodha are found in the fourth chapter of the Hathapradīpikā. Verses of the Yogabijja and Sivasamhitā are in the third chapter. See Bouy (1994: 82); Mallinson, forthcoming.

40. For general remarks on the terminology of the Dattātreyayogaśāstra, see Birch (2011: 548n146).

41. The first chapter of the Amanaska was probably written later than the second. Its terminus ad quem is the sixteenth-century Yogacintāmani of Śivānandasarasvatī, and the absence of its verses from earlier anthologies such as the Hațapradīpika suggests it was written between the fifteenth and sixteenth centuries.

42. For the sources of the Hathapradīpika $\bar{a}$, see the appendix in Mallinson, forthcoming.

43. Śīnivāsayogī’s Haṭaratnāvalī 2.104-2.105ab: "If one's semen is always stable, longevity increases, [for] semen alone is the cause of birth, life, and death. Because [of this], one becomes a rājayogin and certainly not otherwise" (āyusyam vardhate nityam yadi binduh sthiro bhavet I utpattisthitisamhāare bindur eko hi kāranam II tato bhaved rājayogī nāntarā bhavati dhruvam). Śrīnivāsayogī’s willingness to redefine Rājayoga is also seen in his rewriting of verse 2.30 from the Hathapradipika in order to define Rājayoga as: "The [yogin] who is capable of Kevala Kumbhaka 
can hold the breath [whenever and as long] as desired. Such is said to be Rājayoga, there is no doubt about it" (śaktah kevalakumbhena yatheștam vāyudhāraṇam I etādṛso rājayogo kathito nātra saṃśayah). Compare Hațapradīpikā 2.74: śaktah kevalakumbhena yatheșțạ vāyudhāraṇāt I rājayogapadam cāpi labhate nātra saṃsayah.

44. Verse 137 of the Adyar edition of the Yogaśikhopanisat is not in any of the following manuscripts of the Yogabija which I have consulted: ms. 7851 (accession number 4732-17) at the Ganganath Jha Kendriya Sanskrit Vidyapeeth, Allahabad; mss. 1854 and 1857 at the Man Singh Pustak Prakash, Jodhpur; mss. 2287 (accession number 16329) and 2288 (accession number 16927) at the Rajasthan Oriental Research Institute, Jodhpur; ms. 8627 (called the Yogabijaprakaranam) at Deccan College Library, Pune; and mss. A0939-19 and A0061-12 at the Nepal-German Manuscript Preservation Project, Kathmandu National Archives.

45. Yogaśikhopanișat $1.137 \mathrm{~cd}$ : rajaso retaso yogād rājayoga iti smrtah. The idea of samādhi as the union of menstrual blood and semen may have emanated from the belief that the mind is absent at the time of conception (that is, when semen and menstrual blood unite). For example, see $S v a$ bodhodayamañjarī 6ab: "At the time of fusion of semen and menstrual blood, the mind is nowhere [to be found]" (śukraśonitasamśleșakāle nāsti manah kvacit I 6a śukraśoṇita ] correction : śukrașoṇita ed.).

46. Bouy (1994: 105n414) consulted a manuscript of the Yogasiddhāmrta at the Sarasvati Mahal Library in Tanjore. There is one other manuscript by this name in the Government Oriental Library, Mysore (Kaivalyadhama 2005: 334). I am yet to consult either of these manuscripts, but if they are the only manuscripts to preserve this text, then it appears that this is a South Indian transmission of the Yogabija.

47. It has been suggested that the occurrence of rājayoga in a verse immediately following a description of the practice of Vajrolī Mudrā in the Yogatattvopanișat (128-129) confirms that Rājayoga was associated with a sexual practice, albeit as a mental state (Schreiner 2013: 761). This is only true in so far that Rājayoga was associated with Hațhayoga, for the description of Vajrolī Mudrā in the Yogatattvopanișat is at the end of a passage describing the Hathayogic mudrās. Following this passage, one should read tato bhaved rājayogo in Yogatattvopanisat 129a as "from [all the above practices taught in this text], samādhi arises." The Yogatattvopanisat is a truncated version of the Dattātreyayogaśāstra, 
and unfortunately its redactor omitted the line etaih sarvais tu kathitair abhyaset kālakälatah before 129a which makes it undoubtedly clear that all the Yoga practices described above this verse bring about Rajjayoga (and not just the practice of Vajrolī).

48. See Jogapradīpyaka 551-560, in which Vajrolī is also called Vīraj Mudrā, and Sarvāngayogapradīpikā 3.14. I wish to thank James Mallinson for these references.

49. These stages are also in the Mokssopayya, an earlier, tenth-century Kashmirian version of the Yogavāsiștha (Hanneder 2009: 64). It seems that Narahari's conception of Rājayoga includes not only the fourteen stages of Yoga, but all the sections of the text following it, for his first verse (section 14) on Rājayoga says: "Beginning with the division of [fourteen] stages up to the completion of the text, Rājayoga is explained in this profound [work called the] Bodhasāra" (bhūmikäbhedam ārabhya yāvad granthasamāpanam | agādhabodhasāre 'smin rājayogo nirūpyate). The commentator, Divākara, affirms this by stating: "...up to the completion of the text means the completion of the text called the Bodhasāra..." (...granthasamāpanam yāvad granthasya bodhasārākhyagranthasya samāpanam...). This would include thirty-eight further sections of the Bodhasāra, and it implies that Rajjayoga is the principal teaching of this Vedāntic text. I wish to thank Jennifer Cover for providing me with this text and commentary.

50. Rājayogabhāṣya, page 1: rājayogah rājña upayukto yogas tathocyate. This text also glosses Rājayoga as "the king of [all] Yogas" (yogānām rājeti va rājayogah). It has been called a commentary on the Mandalabrāhmanopanișat. In fact, in Sastri's edition (1896), the text is presented with the Mandalabrähmanopanișat to illustrate the parallels between the two texts. Furthermore, some colophons of the Rajjayogabhāsya confirm that it is "an expanded Yogaśāstra" (for example, ms. 570, 1884-87 at BORI, folio 4r, line 10: iti śrīsankarācārya viracitam vij̣mbhitayogaśāstrakrte prathamāśsvāsah). Also see the preface to Sastri's edition (1896: iii) for a similar colophon. If it is a commentary on the Mandalabrāhmanopanișat, it would post-date the eighteenth century (for the date of the Mandalabrāhmanopanișat, see Bouy 1994: 44). Bouy suggests that the Maṇdalabrāhmaṇopanișat may have borrowed from the Rājayogabhāsya. If it did so, then it was a case of a more concise text borrowing from one full of the sort of prolixities which are to be expected in an "expanded 
Yoga text." It is more probable that both derive from a common source and parts of the Mandalabrähmanopanișat may well be closer to that source because of their conciseness.

51. In his commentary on the Bodhasāra's first verse on Rājayoga (see note 49 above), Divākara says: "Rājayoga is the Yoga of kings, because rulers can accomplish it even when [they] remain in their position (that is, as kings). In this connection, its [main] characteristic is knowledge concerning the union of the individual self with Brahman" (...räjayogo rājñām nrpānām svasthāne sthitvāpi sādhayitum śakyatvāt tatsambandhī yogo jīvabrahmaikyavisayakajñannalakșaṇo...). I wish to thank James Mallinson for his comments on this passage (personal communication, December 27, 2012).

52. Sānkhyasāra 6.2-3: "One who is not capable of Rājayoga, is suitable for Haṭhayoga. In the Yogavāsiștha, Vasiștha was taught thus by Bhusuṇua; in Rājayoga, one reverts to gnosis and in Hathayoga, the breathing exercises and postures. [Both of] them are important; because they are auxiliaries, one [depends on] the other. They should [both] be practiced according to one's capacity" (aśakto rājayogasya hațhayogo 'dhikāravān I vāsișthe hi vasișthāya bhusuṇdenaivam ìritam II jũānāvrttī rājayoge prānāyāamāsane hațhe I mukhye te 'ngatayānyonyam sevye śaktyanusāratah). This division between gnosis and Yoga (that is, prānāyāma, and so on) in the Yogavāsiștha (5.78.8) goes back to the Mokșopāya (5.78.8): "There are two methods of destroying the mind; Yoga and gnosis, O Rāma. Yoga is the cessation of the [mind's] activity and gnosis is perfect perception" (dvau kramau cittanāsasya yoga jñānam ca rāghava I yogas tadvrttirodho hi jūannam samyagavekșanam). The reference on Rājayoga in the Sānkhyasāra is cited in Schreiner (2013: 763). I wish to thank Jürgen Hanneder for drawing my attention to the reference in the Moksopaya.

53. In the Śrīvāsișthamahārāmāyanatātparyaprakāśa (5.92.33), Ānandabodhendrasarasvatī makes the rather surprising comment: "When one is not able (aśakti) [to do] the practice of Hathayoga, Rājayoga should be practiced" (hațhayogābhyāsāsaktau rājayogo 'bhyasanīya ity āha). The statement is surprising because in medieval Yoga texts Rājayoga is usually recommended to only the most gifted students, and those incapable of practicing it are prescribed Hathayoga (on the various types of student suited to Mantrayoga, Layayoga, Hațhayoga, and Rājayoga, see Birch 2011: 546n135). However, in a subsequent comment on the term "hatha" 
in Yogavāsiṣtha 5.92.37, Ānandabodhendra defines it as those practices not sanctioned by true scriptures or gurus: "Even though stopping the breath is a forceful [practice] because it is a method of suppressing [that which] is difficult [to restrain], other forceful [methods] in the form of brutal actions such as sitting and lying down [for a long time], withering the body [that is, fasting], [malicious] spells and amulets and cremationground practices, which are not on the path taught by true scriptures and gurus, are prohibited here..." (yadyapi prānasaṃrodhanam durdāntadamanopāyatvād dhațha eva, tathāpi sacchāstragurūpadiștamārgarahitā anye copaveśanaśayanakāyaśoṣaṇamantrayantraśmaśānasādhanādisāhasarūpā hathā atra nivāryanta... II -mārgarahitā ] conjecture Mallinson : -mārgarahito ed.). Thus, those incapable of practicing Hațhayoga are those who would not do so because its methods are prohibited. More importantly, Annandabodhendra's comment reveals that he did not consider the term "hatha" in Yogavāsiṣtha 5.92 to refer to the Haṭhayoga of āsana, prāṇā$y \bar{a} m a, m u d r \bar{a}$, and so on. One can infer that by Rājayoga, he meant those practices taught in this section of the Yogavassistha, which are summarized in 5.92.35ab-36: "The attainment of spiritual knowledge, association with the wise, abandoning habitual tendencies ( $v \bar{a} s a n \bar{a})$ and stopping the movement of the breath. According to tradition, these methods are powerful in conquering the mind" (adhyātmavidyādhigamah sādhusangama eva ca II vāsanāsamparityāgah prānaspandanirodhanam I etās tā yuktayah puștāh santi cittajaye kila). Thus, for Ānandabodhendra, Rājayoga included the practice of prānāyāma as it was taught in the Yogavāsiștha. The reference on Rājayoga in the Śrīvāsisṭhamahārāmāyanatātparyaprakāśa is cited in Schreiner (2013: 762).

54. In the commentary called the Saubhāgyabhāskara on the Śīlalitāsahasranāmastotra (180), the eighteenth-century Bhāskararāya mentions Sānkhya, Tāraka, and Amanaska as the three types of Rājayoga (rājayogo 'pi sānkkhyatārakāmanaskabhedāt trividhaḥ). The Tārakayoga/ Amanaskayoga division may derive from South India, for it is present in the Amanaska's South Indian recension (but not the North Indian and Nepalese) as well as the South Indian redactions of the Advayatärakopanișat and Maṇalabrāhmanopanișat.

55. Gherandasaṃhitā 7.4-6 (for a translation, see Mallinson 2004: 120-23).

56. GOMLM (Government Oriental Manuscripts Library, Madras), ms. 
4377. For details, see GOMLM Catalog (1910: 3263-64). A transcript R635 of this manuscript is in Kaivalyadhama's Library, Lonavla.

57. GOMLM, ms. 4378. For details, see GOMLM Catalog (1910: 3265). There is also a paper manuscript of this text in the Prājña Pāṭhaśālā Maṇuala in Wai; ms. 399 (L. number 6-4).

58. Adyar Library; ms. PM1428 (transcript number TR1163). The colophon attributes the text to a Śankkarācārya.

59. GOMLM, ms. 4374. For details, see GOMLM Catalog (1910: 3259-60). Further research is needed to determine whether manuscripts of similar titles in the GOMLM and Adyar Library are related to those mentioned above; for example, the Rajjayogarahasya (Adyar, ms. 72327), the Rājayogakrama (Adyar, ms. 24-F11), the Rājayogaprakaraṇa (Adyar, ms. 70290), the Rājayogalakșanavicāra (GOMLM, ms. D15980), and so on.

60. Ms. 4378: iti śrīrājayogasiddhāntarahasye vedāntasāre īsvaromāsaṃvāde sakalarājayogāmrte dvitīyah pațalaḥ; ms. 399: iti śrīrājayogasiddhāntarahasye rājayogämrte dvitīyah patalah. Ms. 399 contains another two chapters which are probably a late addition to the text because they mainly consist of verses borrowed from the Amanaska. Ms. 4378 has only two chapters, and these are almost identical (albeit with numerous variant readings) to the first two chapters of ms. 399.

61. The beginning of the Rajjayogasiddhāntarahasya (ms. R635, page 1, lines 1-12) has clear parallels in verses 6-10 (ms. PM1428, page 2, line 6-page 3, line 5) of the Rajjayogasāra, which occur after five verses of salutation to Siva; verse 10 is found in both the Rajjayogasiddhāntarahasya (ms. 4378, page 2, lines 19-20) and the Rajayogämrta (ms. 399, folio $1 \mathrm{r}$, line 3). There are approximately eighteen parallel verses in the Rājayogasāra and Rājayogasiddhāntarahasya.

62. The following passage from the Rājayogasiddhāntarahasya (ms. R635, page 10, lines 9-14) is a good example of this: "Having first practiced Hathayoga, spontaneous retention [arises] abruptly. [Then,] union of [the mind] in an internal sound [occurs] during the retention. Because of the internal sound, an [internal] light shines forth. Having seen the light in the heart-space, [the yogin] is undoubtedly free. [The practice of] āsana is for the destruction of diseases, prānāyāma for [the destruction of] sin. Then, the mind becomes steadier in the [practice of] fusing [the mind] with the internal sound. When the light shines [in the heart], 
liberation [arises.] There is no other means to release [from samsāara]" (ādau kṛtvā hațhābhyāsam haṭhāt kevalakumbhakam I kumbhakānte nādayogo nādāj jyotihprakāśakam I jyotir dṛsțā hrdākāsé sa mukto nātra saṃśayaḥ I āsanam vyādhināśāya prāṇāyāmena pātakah! I atha nādānusandhāne cittam sthirataram bhavet I jyotihprakāse kaivalyam nānyathā muktisādhanam I jyotihprakāse ] ms. 4378 (ma-vipulā) : jyotihprakāśa ms. R635).

63. Rājayogasiddhāntarahasya, ms. R635, page 3, lines 8-10: nirmalam gaganākāram svayamjyotihprakāsásam I tasya madhye nādabindukalāyuktam sadā smaret I rājayoga iti prokto yoginām mokṣadāyakah.

64. Rājayogasiddhāntarahasya, ms. R635, page 4, lines 4-5: pūrnanāde manor aikyam rājayogābhidhānakam I guruvākyena labhyate nānyathā granthikoțibhih.

65. Rājayogasiddhāntarahasya, ms. R635, page 4, lines 6-7: suṣumnā manasā drṣtvā nādam śrutvā nirantaram I nādāntarjyotisaṃvīkṣyo rājayoga udāhṛtah || nādāntar ] rājayogāmrta ms. 399 : nādānte ms. R635. rājayoga ] emendation : rājayogah ms. R635.

66. Rājayoga, ms. 4374, folio 30r: "The lord said: 'I shall speak about the highly purifying Rājayoga which should be adopted by sages. It brings about liberation to its practitioners and increases longevity and health' " (śrībhagavān uvāca | rājayogam aham vakṣye munigrhyam supāvanam | sevakānām mokșakaram āyurārogyavardhanam).

67. Also, these Rājayoga texts have not been cited in the following three chapters of the Upāsanāsārasangraha: the sușumnā-, jīvaparamātmasvarūpopāsanā-, and abhyāsayogaprakaraṇas. As Bouy (1994: 90-91) noted, this compendium is of great value in dating Yoga texts written before the seventeenth century, and a search of its entire contents is needed here, but I have only had access to an IFP transcript (T1095b) which contains the above three chapters.

68. For a discussion on this and a translation of the relevant passages, see Birch (2011: 543n119).

69. Yogasiddhāntacandrikā 1.34: "In the tradition, Hathayoga is spoken of as prānayama: "the sun is known by the syllable "ha," the moon by the syllable "tha." The union of sun and moon is called Hathayoga.' [Therefore,] Hathayoga whose [main] characteristic is the union of sun and moon, [that is,] prānāyāma, is known as prānāyāma in the Yogabīja" (prāṇāyāmasya hațhayogatvam uktam smrtau-hakāreṇa tu sūryo 'sau 
thakārenendur ucyate | sūryācandramasor aikyam hațha ity abhidhīyate | sūryacandrākhyayoh prāṇāyāmayor aikyalakșaṇah haṭhayogo yogabīje prānāyāmah prakīrtita iti l yogabīje ] conjecture : yogabijjam ed.). In Nārāyaṇatīrtha's commentary on Yogasūtra 2.46, he lists thirty-eight postures and quotes without attribution descriptions of them from texts such as the Hathapradīpika , so one could argue that Nārāyanatīrtha integrated Hațhayoga in Aștāngayoga's āsana and prānāayamma. However, he only expressly mentions Hațayoga in regard to prānāyāma.

70. Yogasiddhāntacandrikā 1.20: tato paravairāgyād asamprajñāta itareșām pūrvavilakșānām manuṣānāạn mumukșūnām bhavatīty arthah! ayam eva ca rājayoga ity ucyate. For a translation of this passage, see Birch (2011: 543n120).

71. I am yet to determine a terminus a quo for the Tattvabinduyoga, but it is unlikely to have been written before the seventeenth century. The firmest terminus ad quem for the Tattvabinduyoga is a manuscript (BORI ms. 664, 1883-84) completed in 1810 CE (samvvat 1867). Another manuscript (VSUL 30019) which is reported in Kaivalyadhama's catalog of Yoga manuscripts (2005: 104-5) is dated at 1841, but there is no mention of saka or samvat. If it is the latter, then the manuscript evidence would confirm a terminus ad quem of $1784 \mathrm{CE}$. The New Catalogus Catalogorum (1974: 60) reports that the Tattvabinduyoga is cited by Sundaradeva in his Hathasañketacandrikā. Unfortunately, the Hathasanketacandrik $\bar{a}$ does not help to fix an earlier terminus ad quem for the Tattvabinduyoga, because it was composed sometime between the early seventeenth century (that is, Śivānandasarasvatî’s Yogacintāmanii) and $1832 \mathrm{CE}$, the latter date being based on that of an incomplete manuscript in the Cambridge University Library (ms. Add. 2145). I have noted this in case the date of composition of the Hathasanketacandrikä becomes known.

72. Manuscripts of these names are reported in Kaivalyadhama's catalog of Yoga manuscripts (2005: 102-5, 246-47, 394-95), and they are attributed to a Rāmacandra. The colophon of the manuscript consulted by me (that is, BORI ms. 664, 1883-84) gives the name of the text as the Tattvabinduyoga which has been adopted above.

73. Prānatoșin̄i, part 6, pages 830-48. According to sources cited in Goudriaan and Gupta (1981: 147), this work was completed in 1820 and printed in 1824. For an example of one of its parallel passages to the Tattvabinduyoga, see note 76 below. 
74. Tattvabinduyoga, folio 7v, lines 4-folio 8r, line 3: "Now, Hațhayoga is explained [as follows]. The practice of [stopping] the breath is accomplished by such methods such as exhalation, inhalation, and retention. And then, purification of the body occurs by means of the six cleansing practices such as dhauti. When the entire breath remains in the sun channel, then the mind becomes still. When the mind is still, direct perception of one's essential nature as bliss manifests. Because of [this] Hathayoga, the mind dissolves into the void. Death does not go near [that yogin]. Now, the second type of Hathayoga is explained. Some white, yellow, blue, [or] red form with the splendour of ten million suns is visualized [by the yogin] in his body from his feet up to his head. Because of meditation on that [form], disease and [excessive] heat do not occur in his body and the length of his life increases" (idānīm hațhayogah kathyate I recakapūrakakuṃbhaka ityādiprakārena pavanasādhanam kartavyam I atha ca dhautyādișatkarmakaran̄āt śarīrasya śuddhir bhavati I sūryanādīmadhye pavanạ pūrno yadā tișthati tadā mano niścalam bhavatil manaso niścalatve ānandasvarūpapratyakșam bhāsate I hațhayogakaraṇāt manah sünyamadhye linnam bhavati I kālah samīpe nāgacchati I idānīm haṭayogasya dvitīyo bhedah kathyate I padārabhya śirahparyantạn svaśarīre koṭisūryatejahsamānam śvetam pītam nīlam raktam kị̣ cid rūpam cintyate I taddhyānakaran̄āt sakalānge rogajvalanam na bhavati I āyurvrddhir bhavati II kālah ] conjecture : kalāh codex. hathayogasya ] conjecture : hathayoga codex. It is possible that rogajvalanam is a corruption of rogajvaro; a stronger digestive fire ([jvalana] is usually a desired outcome of Hathayoga).

75. Tattvabinduyoga, folio 2r, lines 4-5: "He who causes such [mental states] as patience, discriminative judgment, detachment, peacefulness, and contentment to arise in his mind, he alone is said to be a yogin of [these] many Kriyās" (yasyāntaḥkaraṇe kṣamāvivekavairāgyaśāntisaṇtoṣa ityādinny utpādyante, sa eva bahukriyāyogī kathyate).

76. Tattvabinduyoga, folio 7r, line 1: idānīm rājayogayuktasya puruṣasya yac charīracihnam kathyate I ...yasya janmamarane na stah sukham na bhavati, kulam na bhavati, śîtalam na bhavati, sthānam na bhavati, asya siddhasya manomadhye īsvarasambandhī prakāso nirantaram pratyakṣo bhavati I sa ca prakāśo na síto na coṣno na śveto na pīto bhavati | tasya na jātir na kim cic cihnam I ayam ca niṣkalo nirañjanah alakṣaś ca bhavati. Compare Yogasvarodaya (cited in the Prānatoṣiṇi, part 6, page 
834): na kṣobho janma mrtyuś ca na duḥkhạ̣ na sukhạ̣ tathā I bhedābhedau manahsthau na jūānam śīlam kulam tathā I prakāśakuśasambandhiprasango 'yam nirantaram I sarvaprakāśako 'sau tu naștabhedādir eva ca I asya jāter na cihnañ ca niṣkalo 'yam nirañjanah.

77. I wish to thank James Mallinson for this reference.

78. For similar wordplay, see the Amanaska's second definition of rājayoga (note 22 above) as well as Nārāyanatīirtha's definition (cited above on page 414-15).

79. Sarvāñgayogapradīpikā 3.13cd: rājayog sab upar chājai I jo sādhai so adhika virājai. My reading of this hemistich follows the commentary of the editor, R. C. Misra: rājayog = yog kā ek prakār $\mid$ yah any yogaprakārom se sarvaśreșțh batāyā gayā haim 1 ... I jo ise sādhatā hai, vah adhik der tak [-lambe jīvan tak] śobhāyamān banā rahtā hai I chājai = sobhāyamān.

80. Sarvāñgayogapradīpikā 3.18-19: rājayogi ke lakșaṇ esai, mahāpuruș baulai haị̣ taise I jākaum dukh aru sukh nahị̣ hoī, harṣ śok vyāpai nahīm kō̄ II jākaim kṣudhā tuṣā na satāvai, nidrā ālasa kabahu na āvai I sít uṣn jākaim nahị̣ bhā̄, jarā na vyāpai kāl na șā̄i. Compare Haṭapradīpikā 4.108 and 4.111: khädyate na ca kālena bādhyate na ca karmaña I sādhyate na sa kenāpi yogì yuktah samādhinā II ...na vijānāti śitoṣnam na duḥkhạ̣ na sukham tathā I na mānam nopamānam ca yogī yuktạ̣ samādhinā.

81. My research on the Yoga traditions which date from the twelfth century onwards certainly confirms this view. However, there are occurrences of Aștānngayoga being interpreted independently of Pātañjalayoga before this time (for example, Netratantra 8.10-21). David Gordon White informs me that he has discussed expositions of Aștānngayoga that differ from that of the Yogasūtra, in five Purānas including the early Viṣnupurāna (6.7), in his forthcoming book, The Yoga Sutra of Patanjali: A Biography (2014) (personal communication, January 10, 2013).

82. For examples of the various traditions in which Aștāngayoga is found, see Birch (2011: 541n103).

83. Apart from the Bhāgavatapurāna, other Vaiṣnava texts which incorporated Aștānggayoga include the Viṣnupurāṇa and the Pāñcarātrika Ahirbudhnyasaṃhitā, as well as the Vasișthasamhitā, the Yogayajjñavalkya and the Dattātreyayogaśāstra. Some Saiva works such as the Netratantra and the Agnipurāṇa have also incorporated Aṣțāngayoga. 


\section{References Cited}

Akhilananda, Swami. 2001 [1948]. Hindu Psychology: Its Meaning for the West. Taylor and Francis e-Library [internet].

Amanaska. See Birch 2013.

Amaraughaprabodha. See Mallik 1954.

Ānandakanda. 1952. Ānandakanda (ed. S. V. Radhakrishna Sastri). Tanjore: Tanjore Sarasvati Mahal Sanskrit Library.

Aparokṣānubhūti. 1988. Aparokṣānubhūtih_-Vidyāranyakṛtayā Aparokṣadīpikākhyațīkayā Samvvalitā (ed. Kamla Devi). Allahabad: Akshayavata Prakashan.

Bhāgavatapurāṇa. 1983. Śrīmadbhāgavatapurānam with the Tīkā Bhāvārthabodhinā of Śrīdharasvāmin (ed. Jagadisalala Sastri). Delhi: Motilal Banarsidass.

Birch, Jason. 2011. "The Meaning of Hața in Early Hațhayoga." Journal of the American Oriental Society 131, 4: 527-54.

Birch, Jason. 2013. "The Amanaska: King of All Yogas. A Critical Edition and Annotated Translation with a Monographic Introduction" Ph.D. Dissertation. Oxford: University of Oxford Library.

Bodhasāra. 2010. Bodhasāra: An Eighteenth Century Sanskrit Treasure by Narahari (trans. Jennifer Cover and Grahame Cover). Charleston: CreateSpace.

Bouy, Christian. 1994. Les nātha-yogin et les Upanisads: étude d'histoire de la littérature hindoue. Paris: Diffusion de Boccard.

Brahma Kumaris. 1986 [1981]. Positive Health: Raja Yoga Meditation for Stress-Free, Peaceful and Healthy Life. Delhi: Prajapita Brahma Kumaris Ishwariya Vishwa Vidyalaya.

Brahma Kumaris. 1996. Raja Yoga: New Beginnings. Delhi: Prajapita Brahma Kumaris Ishwariya Vishwa Vidyalaya.

Bṛhadāranyakopanișat. See Olivelle 1998.

Bụhannāradīyapurāṇa. 1984. The Nāradīyamahāpurānamam (ed. N. S. Singh). Delhi: Nag Publishers.

Bronkhorst, Johannes. 1993. The Two Traditions of Meditation in Ancient India. Delhi: Motilal Banarsidass.

Chandra, Ram. 2009 [1989]. The Complete Works of Ram Chandra. Volume 1. Calcutta: Spiritual Hierarchy Publication Trust.

Cover, Jennifer. 2012. "An 18th century Illumination of the Seven Steps 
of Raja-Yoga." Paper Presented at the 15th World Sanskrit Conference, January 5-10, Delhi, India.

Daniélou, Alain. 1991 [1949]. Yoga: Mastering the Secrets of Matter and the Universe. Rochester: Inner Traditions International.

Dattātreyayogaśāstra. N.d. Dattātreyayogaśāstra (ed. James Mallinson, compiled with assistance from Alexis Sanderson, Jason Birch, Péter Szántó, and Andrea Acri). Unpublished.

De Michelis, Elizabeth. 2004. A History of Modern Yoga: Patañjali and Western Esotericism. London: Continuum.

Dhātupātha. 1969. Dhātupātha of Pānini (ed. Kanaka Lal Sharma). Haridas Sanskrit Series 281. Varanasi: Chowkhamba Sanskrit Series Office.

Durai, A. P. 2004. Basics of Sahaj Marg. Online book: http://shivanand. tripod.com/download/meditationBASICS.htm (accessed January 12, 2013).

Dvivedi, Manilal Nabhubhai. 1885. Rája Yoga, or The Practical Metaphysics of the Vedánta: Being a Translation of the Vákyasudhá or Drigdrishyaviveka of Bháratitirtha, and the Aparokshánubhuti of Shri Shankaráchárya. Bombay: The "Subodha-Prakasha" Printing Press.

Endo, Ko. 1998. "The Medieval Yoga-s and the Patanjala-Yoga: Narayana Tirtha's Interpretation of the Yogasutra." The Journal of the Faculty of Letters, Nagoya University. Philosophy 44: 25-39.

Feuerstein, Georg. 2001 [1998]. The Yoga Tradition: Its History, Literature, Philosophy and Practice. Prescott: Hohm Press.

Frauwallner, Erich. 1973 [1953-56]. History of Indian Philosophy. Volume 1: The Philosophy of the Veda and of the Epic; the Buddha and the Jina; the Sämkhya and the Classical Yoga-System (trans. V. M. Bedekar). Delhi: Motilal Banarsidass.

Gharote, M. L. and Vijay Kant Jha, eds. 2002. Yuktabhavadeva of Bhavadeva Miśra. Lonavla: Lonavla Yoga Institute.

Gheraṇụasaṃhitā. See Mallinson 2004.

Gode. P. K. 1953. Studies in Indian Literary History. Volume 1. Bombay: Bharatiya Vidya Bhawan.

GOMLM (Government Oriental Manuscripts Library, Madras) Catalog. 1910. A Descriptive Catalogue of the Sanskrit Manuscripts in the Government Oriental Manuscripts Library, Madras. Volume 9: Systems of Indian Philosophy: Vaiśeșika, Yoga, Mīmāmsāa and Vedānta-Advaita Philosophy (eds. M. Rangacarya and Rao Bahadur). Madras: Superin- 
tendent, Government Press.

Goudriaan, Teun and Sanjukta Gupta. 1981. Hindu Tantric and Śākta Literature. Wiesbaden: Otto Harrassowitz.

Hanneder, Jürgen. 2009. "Dreams and Other States of Consciousness in the Mokṣopāya." In Claudine Bautze-Picron, ed., The Indian Night, Sleep and Dream in Indian Culture, 64-102. Delhi: Rupa.

Hațhapradīpikā. 1972. Hațhapradīpikā of Svātmārāma with the Commentary Jyotsnā of Brahmānanda (ed. K. Kunjunni Raja). Madras: Adyar Library and Research Centre.

Hațhapradīpikā. 1998. Haṭhapradīpikā of Svātmārāma (eds. Swami Digambarji and Pandit Raghunatha Sastri Kokaje). Lonavla: Kaivalyadhama Srimanmadhava Yogamandira Samiti.

Hațharatnāvalī. 2002. Hațharatnāvalì of Śrīnivāsayogì (eds. M. L. Gharote, Parimal Devnath, and Vijay Kant Jha). Lonavla: Lonavla Yoga Institute.

Hațhatattvakaumudī. 2007. Hațatattvakaumudī of Sundaradeva (eds. M. L. Gharote, Parimal Devnath, and Vijay Kant Jha). Lonavla: Lonavla Yoga Institute.

Iyengar, B. K. S. 1979. Light on Yoga (Yoga Dīpikā). New York: Schocken Books.

Jogapradīpyakā. 2006. Jogapradīpyakā of Jayatarāma (eds. Swami Mahesananda, and B. R. Sharma, G. S. Sahaya and R. K. Bodhe). Lonavla: Kaivalyadhama Srimanmadhava Yogamandira Samiti.

Jyotsnā. 2002. Hațapradīpikā Jyotsnā of Brahmānanda (eds. Swami Mahesananda, and B. R. Sharma, G. S. Sahaya and R. K. Bodhe). Lonavla: Kaivalyadhama Srimanmadhava Yogamandira Samiti.

Kaivalyadhama. 2005. Descriptive Catalogue of Yoga Manuscripts (Updated) (comp. Philosophico-Literary Research Department). Lonavla: Kaivalyadhama S.M.Y.M Samiti.

Kaulajñānanirṇaya. Kaulajñānanirṇaya, manuscript NAK 3-362 (NGMPP reel A48/13), National Archives at Kathmandu, Nepal.

Kaulajñānanirṇaya. 1934. Kaulajñānanirṇaya and Some Minor Texts of the School of Matsyendranātha (ed. Prabodh Chandra Bagchi). Calcutta Sanskrit Series 3.

Larson, Gerald James. 2009. "Differentiating the Concepts of 'Yoga' and 'Tantra' in Sanskrit Literary History." Journal of the American Oriental Society 129, 3: 487-98.

Mahābhārata. 1933-66. The Mahābhārata for the First Time Critically 
Edited (eds. V. S. Sukthankar, S. K. Belvalkar, and P. L. Vaidya, general editors, and others). 19 volumes. Poona: Bhandarkar Oriental Research Institute.

Mak, Bill M. 2013. "The Date and Nature of Sphujidhvaja's Yavanajātaka Reconsidered in the Light of Some Newly Discovered Materials." History of Science in South Asia 1: 1-20.

Mālinīślokavārttika. 1921. Mālinīvijayavārttika of Abhinavagupta (ed. Madhusudan Kaul). Kashmir Series of Texts and Studies 31.

Mallik, Kalyani. 1954. Siddha-Siddhānta-Paddhati and Other Works of the Nātha Yogìs. Poona: Poona Oriental Book House.

Mallinson, James. 2004. The Gheranda Samhita: The Original Sanskrit and An English Translation. Woodstock: Yoga Vidya.

Mallinson, James. 2007. The Shiva Samhita: A Critical Edition and an English Translation. Woodstock: Yoga Vidya.

Mallinson, James. Forthcoming. "Hathayoga's Philosophy: A Fortuitous Union of Non-Dualities." Journal of Indian Philosophy.

Mokṣopāya. 2013. Mokṣopāya: Upaśāntiprakaraṇa (eds., Susanne KrauseStinner and Peter Stephan). Wiesbaden: Harrassowitz.

Neff, Mary K. 2003 [1937]. Personal Memoirs of H.P. Blavatsky. Whitefish: Kessinger Publishing.

Netratantra. 1926, 1939. Netratantra with the Commentary (Netroddyota) of Rājānaka Ksemarāja (ed. Madhusudan Kaul). Kashmir Series of Texts and Studies 46, 59.

New Catalogus Catalogorum. 1974. New Catalogus Catalogorum: An Alphabetical Register of Sanskrit and Allied Works and Authors (ed. Kumarapuram Kunjunni Raja). Volume 8. Madras: University of Madras.

Olivelle, Patrick, trans. and ed. 1998. The Early Upanisads: Annotated Text and Translation. New York: Oxford University Press.Paul, N. C. 1882 [1851]. A Treatise on the Yoga Philosophy. Benares: Medical Hall Press.

Pingree, D. E. 1981. Jyotihśāstra: Astral and Mathematical Literature. Wiesbaden: Otto Harrassowitz.

Prāṇatoṣiṇī (of Rāmatoṣaṇa Vidyālaṃkāra). 1898. Prānatoṣinī (ed. J. V. Bhattacaryya). Calcutta: Srijivananandavidyasagarabhattacarya.

Rājayoga (of Agastya). Rājayoga, manuscript 4374, Government Oriental Manuscripts Library, Madras.

Rājayogabhāṣya. Rājayogabhāṣya, manuscript 570, 1884-87, Bhandarkar 
Oriental Research Institute Library, Pune.

Rājayogabhāṣya. 1896. Maṇalabrahmaṇopaniṣad with a Commentary (Rājayogabhāşya) (ed. Mahadeva Sastri). Government Oriental Library Series. Mysore: Government Branch Press.

Rājayogāmrtta. Rājayogāmṛta, manuscript 399 (L. number 6-4), Prajna Pathasala Mandala, Wai.

Rājayogāmṛta. Rājayogāmṛta, manuscript 4378, Government Oriental Manuscripts Library, Madras.

Rājayogasāra. Rājayogasāra, manuscript PM1428, Adyar Library, Chennai.

Rājayogasiddhāntarahasya. Rājayogasiddhāntarahasya, transcript R635 (based on manuscript D4377), Kaivalyadhama Library, Lonavla.

Rama, Swami. 1998 [1979]. The Royal Path: Practical Lessons on Yoga. Honesdale: Himalayan Institute Press.

Rudrayāmalottaratantra. 2002. Rudrayāmalam (Uttaratantram) (ed. Ramakumara Raya). Varanasi: Krsnadasa Academy.

Sanderson, Alexis. 1990. "The Visualization of the Deities of the Trika." In André Padox, ed., L'image divine: culte et méditation dans l'hindouisme, 31-88. Paris: Éditions du CNRS.

Sānkhyasāra (of Vijñānabhikṣu). 1986. Sāṃkhyasāra: Hindī anuvāda sahita (ed. Badari Narayana Pancoli). Delhi: Pancoli Pustakamala Prakasana Samiti.

Saāradātilakatantra. 1996. Śārada-Tilaka-Tantra (ed. Arthur Avalon). Delhi: Motilal Banarsidass.

Śārngadharapaddhati. 1987. Śārngadharapaddhati (ed. Peter Peterson). Delhi: Chaukhamba Sanskrit Pratishthan.

Sarvāngayogapradīpikā. 1992. Sarvāngayogapradīpikā in the Sundargranthāvalī (ed. R. C. Misra). Delhi: Kitabghar.

Satyananda Saraswati, Swami. 1969. Asana Pranayama Mudra Bandha. Munger: Bihar School of Yoga.

Saubhāgyabhāskara. 1935. Lalitāsahasranāmastotram with the Commentary Saubhāgyabhāskara (ed. V. S. Panshikar). Bombay: Panduranga Tavaji Nirnaya Sagara Press.

Schreiner, Peter. 2013. "Yoga: Rāja Yoga." In Knut A. Jacobsen, Helene Basu, Angelika Malinar, Vasudha Narayanan, eds., Brill's Encyclopedia of Hinduism, 760-69. Leiden: Brill.

Singleton, Mark. 2010. Yoga Body: The Origins of Modern Posture Practice. New York: Oxford University Press. 
Sivananda, Swami. 2010 [1937]. Raja Yoga. Tehri-Garhwal: The Divine Life Society.

Śivasaṃhitā. See Mallinson 2007.

Śivayogadīpikā. 1978. Śivayogadīpikā (Sadāśivayogīśvaraviracitā) (ed. Āśramasthapaṇịitāh). Anandasrama Sanskrit Series 139. Pune: Anandasrama Press.

Strauss, Sarah. 2005. Positioning Yoga: Balancing Acts Across Cultures. Oxford: Berg.

Svabodhodayamañjarī. See Torella 2000.

Svacchandoddyota. 1921-35. Svacchandatantra with the Commentary (Svacchandoddyota) of Rājānaka Kșemarāja (ed. Madhusudana Kaul). Kashmir Series of Texts and Studies 31, 38, 44, 48, 51, 53, 56.

Tantrāloka. 1918-38. Tantrāloka of Abhinavagupta with the Commentary (-viveka) of Rājānaka Jayaratha (ed. Mukund Ram Sastri). Kashmir Series of Texts and Studies 23, 28, 30, 35, 29, 41, 47, 59, 52, 57, 58.

Tattvabinduyoga (of Rāmacandraparamahamsa). Tattvabinduyoga, manuscript 664, 1883-84, Bhandarkar Oriental Research Library, Pune.

Thiel-Horstmann, Monika. 1983. Crossing the Ocean of Existence: Braj Bhāṣā Religious Poetry from Rajasthan. A Reader. Wiesbaden: Otto Harrassowitz.

Torella, Raffaele. 2000. "The Svabodhodayamañjarī, or How to Suppress the Mind with no Effort." In Ryutaro Tsuchida and Albrecht Wezler, eds., Harānandalaharī: Volume in Honour of Professor Minoru Hara on His Seventieth Birthday, 387-410. Reinbek: Verlag für Orientalistische Fachpublikationen.

Upāsanāsārasaṅgraha. Upāsanāsārasañgraha, IFP transcript T1095b (based on R2831[i], foliis 116a-139b), pages 15-63. (Available on the Muktabodha website, http://muktalib7.org/IFP_ROOT/access_page.htm). Ūrmikaulārṇavatantra. Ūrmikaulārṇavatantra (ed. Mark Dyczkowski). (Available on the Muktabodha website, http://muktalib7.org/IFP_ROOT/ access_page.htm).

Vasudeva, Somadeva. 2004. The Yoga of the Mālinivvijayottaratantra, chapters 1-4, 7-11, 11-17: Critical Edition, Translation and Notes. Pondicherry: École française d'Extrême-Orient.

Vasudeva, Somadeva. 2012. "The Transport of the Hamsas: A Śākta Rāsalīlā as Rājayoga in Eighteenth Century Benares.” In David Gordon White, ed., Yoga in Practice, 242-54. Princeton: Princeton University 
Press.

Vivekananda, Swami. 2003 [1896]. Raja Yoga. Leeds: Celephais Press.

Ward, William. 1818 [1811]. A View of the History, Literature, and Mythology of the Hindoos: Including a Minute Description of their Manners and Customs and Translations from their Principal Works. Volume 1. Serampore: Mission Press.

Wood, Ernest. 1954. Great Systems of Yoga. New York: Philosophical Library.

Yoga Upanișads. 1968. Yoga Upanișads with the Commentary of Śri Upanisadbrahmayogin (ed. Pandit A. Mahadeva Sastri). Madras: The Adyar Library and Research Centre.

Yogabīja. Yogabījaprakaraṇam, manuscript 8627, Deccan College Library, Pune.

Yogabīja. 1982. Yogabīja of Gorakhanātha (ed. Ramalala Srivastava). Gorakhapur: Gorakhanath Mandir.

Yogacintāmaṇi (of Śivānandasarasvatī). Yogacintāmaṇi, manuscript 9785 (based on R635), Kaivalyadhama Yoga Institute Library, Lonavla.

Yogacintāmaṇi (of Śivānandasarasvatī). N.d. Yogacintāmaṇī (ed. Haridas Sarma). Calcutta: Calcutta Oriental Press.

Yogarājopanișat. Yogarājopanișat, manuscript 46-461, Bharat Itihas Samshodak Mandal, Pune.

Yogarājopanișat. 1938. Unpublished Upanishads (ed. Kunhan Raja). Chennai: Adyar Library.

Yogasārasañgraha. Yogasārasañgraha, IFP transcript T859 (based on D4373). (Available on the Muktabodha website, http://muktalib7.org/ IFP_ROOT/access_page.htm).

Yogasārasañgraha (of Vijñānabhikṣu). 1989. Yogasārasañgraha of Vijñānabhikșu (ed. Ram Shankar Bhattacharya and Goswami Prahlad Giri Vedantakeshari). Varanasi: Bharatiya Vidya Prakashan.

Yogaśāstra. 1977-86. Yogaśāstram (Svopajñavrttivibhūsitam) of Hemacandra (ed. Muni Jambuvijaya). Bombay: Jaina Sahitya Vikasa Mandala.

Yogasiddhāntacandrikā. 1910. Yogadarśanam with a Commentary Called the Yogasiddhāntacandrikā of Nārāyanatīrtha (ed. Paṇịta Ratna Gopala Bhatta). Varanasi: Vidya Vilasa Press.

Yogaśikhopanișat. See Yoga Upanișads.

Yogasūtra. 1904. Pātañjalayogasūtrāṇi (vācaspatimiśraviracitațīkāsamvvalitavyāsabhāsyasametāni...tathā bhojadevaviracitarājamārtaṇd̄ābhidha- 
vrttisametāni (eds. Kasinatha Sastri Agase and Hari Narayana Apate). Anandasrama Sanskrit Series 47. Pune: Anandasrama Press.

Yogavāsisțha. 1918. The Yogavāsiștha of Vālmīki with the Commentary Vāsișthamahārāmayaṇatātparyaprakāśa (ed. Vasudeva Laxman Sastri Panshikar). Bombay: Tukaram Jawaji.

JASON BIRCH is visiting assistant professor in Yoga Studies at Loyola Marymount University, Los Angeles.

letusconnect@hotmail.com 